\title{
PROTEÇÃO DE CACHOS DE BANANEIRA (Musa sp. AAA) EM DIFERENTES ÉPOCAS E PERIODOS, APÓS A EMERGÊNCIA DA INFLORESCÊNCIA
}

JOSÉ NILTON MEDEIROS COSTA

Engenheiro Agrônomo

Orientador: Prof. Dr. JOÃO ALEXIO SCARPARE FILHO

Dissertação apresentada à Escola Superior de Agricultura "Luiz de Queiroz", Universidade de São Paulo, para obtenção do título de Mestre em Agronomia, Área de Concentração: Fitotecnia.

PIRACICABA

Estado de São Paulo - Brasil

Julho - 1998 


\section{ERRATA}

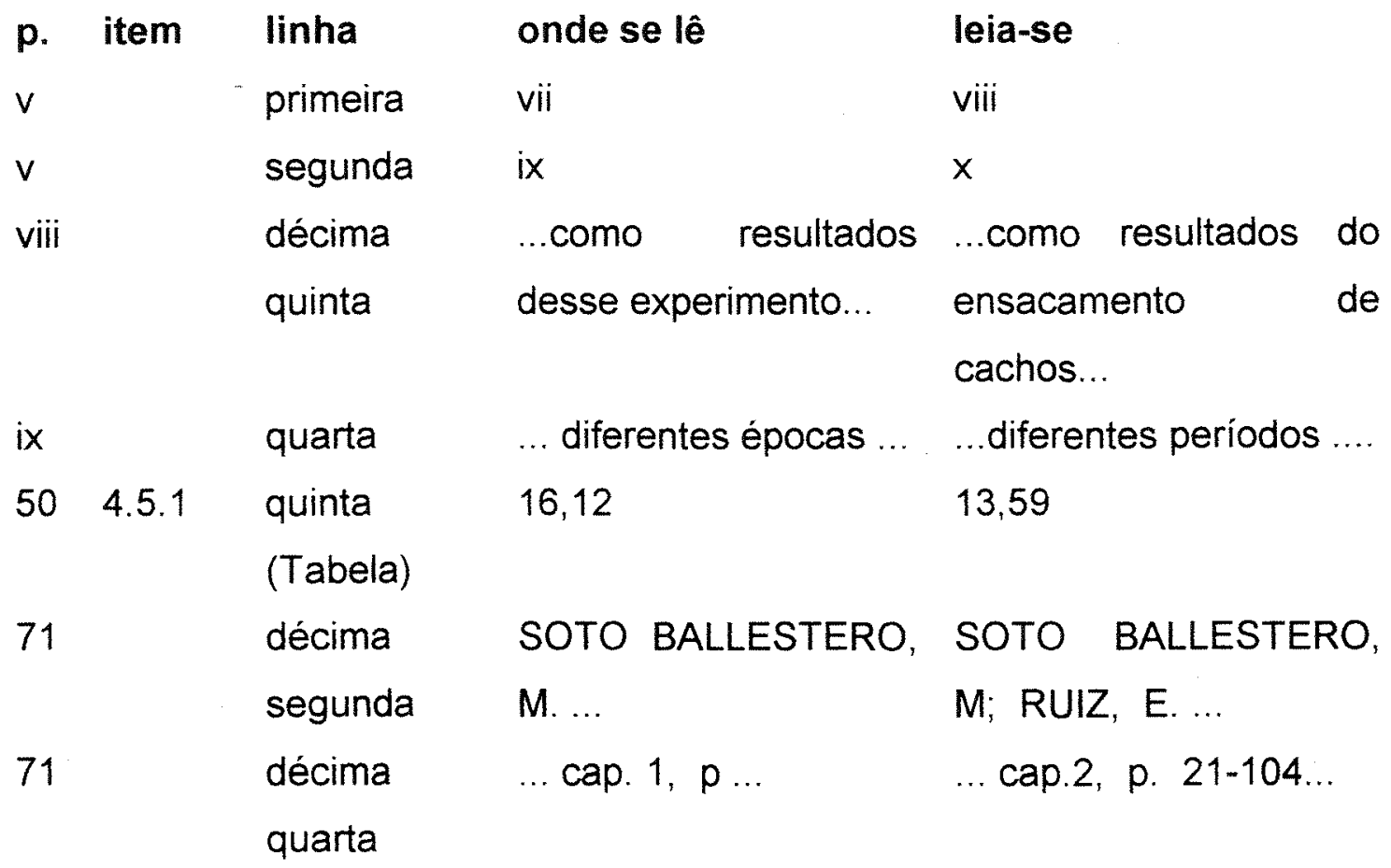


Dados Internacionais de Catalogação na Publicação (CIP)

DIVISÃO DE BIBLIOTECA E DOCUMENTAÇÃO - Campus "Luiz de Queiroz"/USP

Costa, José Nilton Medeiros

Proteção de cachos de bananeira (Musa sp. AAA) em diferentes épocas e periodos, após a emergència da inflorescência / José Nilton Medeiros Costa. - Piracicaba, 1998.

$72 \mathrm{p}$.

Dissertaçāo (mestrado) - Escola Superior de Agricultura Luiz de Queiroz, 1998. Bibliografia.

1. Banana 2. Fruta tropical 3. Inflorescência 4. Proteção de planta 5. Tecnologia agricola I. Titulo

CDD 634.772 
Aos meus pais e irmãos

Com afeto

Ofereço

À minha esposa Vanderli e meus filhos Helber e Engel pelo amor e apoio em todos os momentos

Dedico 


\section{AGRADECIMENTOS}

À Empresa Brasileira de Pesquisa Agropecuária (EMBRAPA), pela oportunidade concedida para realização do Curso de Pós-Graduação em nível de Mestrado.

À Escola Superior de Agricultura "Luiz de Queiroz", pela oportunidade concedida para realização deste curso.

Ao Professor João Alexio Scarpare Filho pela orientação, apoio e amizade.

Ao Professor Ricardo Victória Filho pela atenção e colaboração prestada no âmbito do Departamento de Horticultura.

À Chefia da Embrapa Rondônia, pelo apoio prestado durante o curso.

Ao Sr. João José Pascoal e Família pela cessão do bananal para condução dos experimentos e apoio prestado na execução do trabalho.

À Dra. Rachel Domarco, Dra. Marta H. F. Spoto, Técnica Especializada Clarice Matraia, do Departamento de Entomologia do CENA, pela contribuição na realização das análises físicas e químicas efetudas em laboratório.

À Prof ${ }^{a}$ Maria Izalina Alves, pelos ensinamentos e contribuição para realização da análise estatística. 
Aos colegas da Embrapa Rondônia Marilia Locatelli e Victor F. de Souza, pela amizade, apoio e incentivo a participar deste curso.

Aos colegas de curso Inácio de Barros, Luis Enrique R. Ortigoza, Paulo S. R. de Araújo, Regma S. X. Caetano, Ricardo A. Kluge, Shoey Kanashiro, Valéria A. Modolo e Walter G. R. Robles, pela convivência, amizade e apoio solícito.

Aos colegas Adônis Moreira, Ângela Nunes, César Castro. Francismar Medeiros, José Maria. J. C. Feitosa, Marcone César, Zilton J. M. Cordeiro pela amizade e favorecimento à integração no âmbito discente da pós-graduação.

Aos Funcionários do Departamento de Horticultura da ESALQ, pelo apoio e amizade.

A todos aqueles que contribuiram de alguma forma para que vencesse a caminhada empreendida até ao final deste curso. 


\section{SUMÁRIO}

Páginas

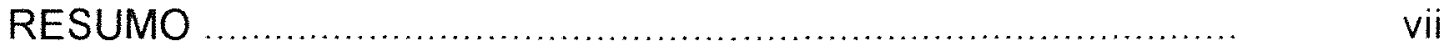

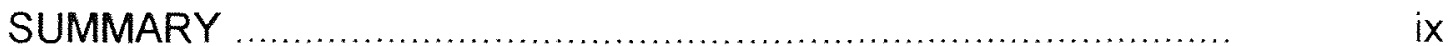

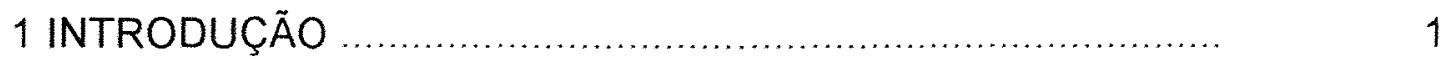

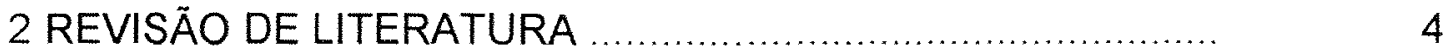

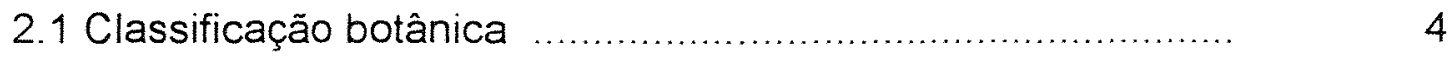

2.2. Biologia do florescimento e frutificação ............................. 4

2.3 Ciclos da bananeira ........................................... 9

2.4 Proteção de cachos de banana na planta com sacos de polietileno ....................................................... 9

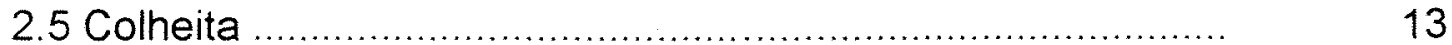

2.6 Amadurecimento e transformações bioquímicas em banana 16

3 PROTEÇÃO DE CACHOS DE BANANEIRA 'NANICÃO' (Musa sP AAA), COM SACOS DE POLIETILENO, EM ÉPOCAS

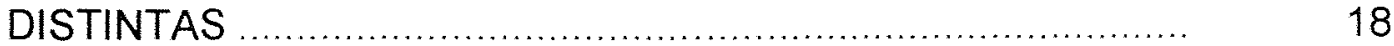

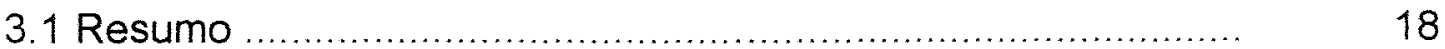

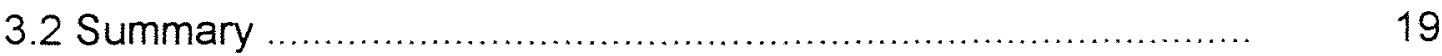

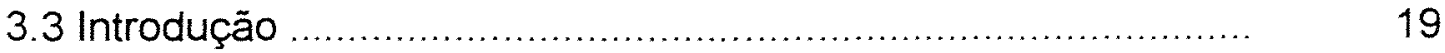

3.2 Material e métodos .............................................. 23

3.2.1 Local do experimento ........................................ 23

3.2.2 Tratamentos ................................................ 23

3.2.3 Variáveis analisadas ............................................. 24

3.2.4 Preparo dos frutos para análise ................................. 26

3.2.5 Delineamento experimental .................................. 26

3.2.6 Análise estatística .............................................. 26

3.3 Resultados e discussão ........................................ 27 
3.3.1 Intervalo entre a emergência da inflorescência e a colheita $(\mathrm{E}-\mathrm{C})$

3.3.2 Peso do cacho

3.3.3 Comprimento, diametro e densidade de frutos

3.3.4 Firmeza da polpa ................................................... 34

3.3.5 Relação polpa/casca ................................................ 35

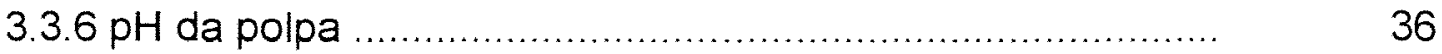

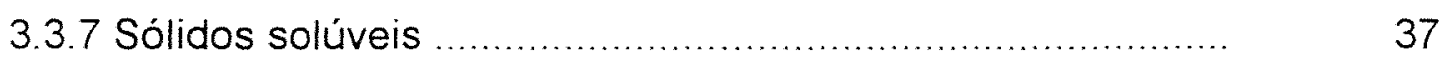

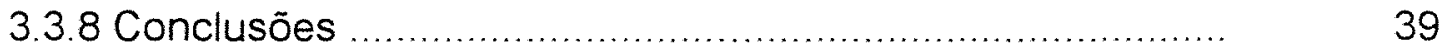

4 PROTEÇÃO DE CACHOS DE BANANEIRA 'GRANDE NAINE' (Musa sp AAA), COM SACOS DE POLIETILENO, EM DIFERENTES PERÍODOS APÓS A EMERGÊNCIA DA INFLORESCÊNCIA .................................................. 40

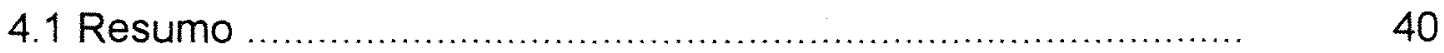

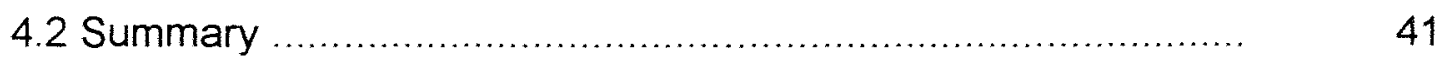

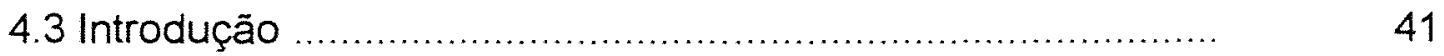

4.2 Material e métodos ...................................................... 44

4.2.1 Local do experimento ................................................ 44

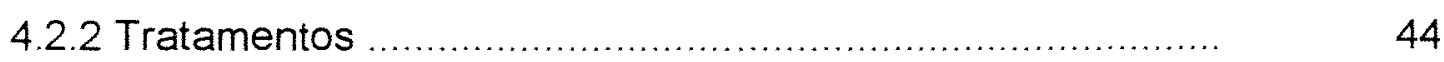

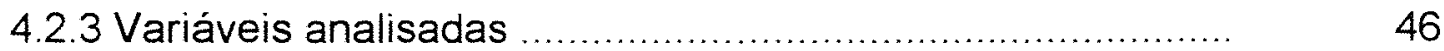

4.2.4 Preparo dos frutos para análise ................................... 47

4.2.5 Delineamento experimental .......................................... 48

4.2.6 Análise estatística ..................................................... 48

4.3 Resultados e discussão .................................................. 49

4.3.1 Intervalo em dias entre a emergência da inflorescência e a colheita ............................................................... 49

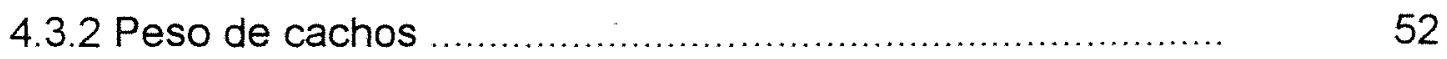

4.3.3 Comprimento de frutos ................................................. 53

4.3.4 Diâmetro de frutos ....................................................... 54 
4.3.5 Densidade ................................................... 56

4.3.6 Firmeza da polpa ................................................ 56

4.3.7 Relação polpa/casca .............................................. 57

$4.3 .8 \mathrm{pH}$ da polpa ..................................................... 58

4.3.9 Sólidos solúveis ................................................ 59

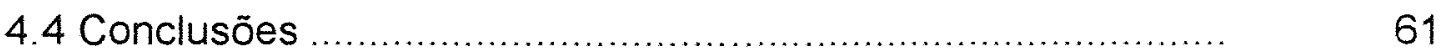

5 CONCLUSÕES GERAIS ....................................... 62

REFERÊNCIAS BIBLIOGRÁFICAS .............................. 64 


\title{
PROTEÇÃO DE CACHOS DE BANANEIRA (Musa sp. AAA) EM \\ DIFERENTES ÉPOCAS E PERIODOS, APÓS A EMERGÊNCIA DA \\ INFLORESCÊNCIA
}

\author{
Autor: JOSÉ NILTON MEDEIROS COSTA \\ Orientador: Prof. Dr. JOÃO ALEXIO SCARPARE FILHO
}

\section{RESUMO}

Foram realizados dois experimentos objetivando avaliar os efeitos do ensacamento de cachos de banana, com sacos de polietileno, nas cultivares Nanicão e Grande Naine. Os experimentos foram efetuados em bananal estabelecido na Fazenda Diamante, Município de Tietê - SP.

O primeiro experimento consistiu da avaliação do ensacamento de cachos de bananeira 'Nanicão', em épocas distintas. Empregou-se o delineamento em blocos ao acaso, em fatorial $2 \times 3 \mathrm{com}$ quatro repetições. $O$ ensacamento foi efetuado com sacos de polietileno e as épocas estudadas foram inverno, verão e outono, definidas pela ocorrência do ciclo completo da estação no período compreendido entre a emergência da inflorescência e a colheita. As variáveis medidas foram: peso do cacho; intervalo entre a emergência da inflorescência e a colheita; comprimento, diâmetro e densidade do fruto; $\mathrm{pH}$; sólidos solúveis; firmeza de polpa e relação polpa/casca de frutos verdes. Para a interação ensacamento $x$ épocas não foi detectada diferença significativa para nenhuma das variáveis. Verificaram-se, como resultados desse experimento, o decréscimo do intervalo entre a emissão da inflorescência e a colheita no inverno e verão, densidades menores que 1,00 no verão e outono e menor teor de sólidos solúveis e firmeza. Não houve 
diferença em relação ao peso de cacho, comprimento e diâmetro de fruto; $\mathrm{pH}$ e relação polpa/casca em frutos verdes.

O segundo experimento objetivou a avaliação do ensacamento de cachos de bananeira 'Grande Naine', em diferentes épocas após a emergência da inflorescência (10, 20 e 30 dias). Utilizou-se o delineamento em blocos ao acaso, com cinco repetições. As variáveis analisadas foram: peso de cachos; intervalo em dias entre emergência da inflorescência e o ponto de colheita para o mercado externo (calibre de $34 \mathrm{~mm}$ de diâmetro dos frutos da $2^{\text {a }}$ penca superior) e mercado interno (calibre de $34 \mathrm{~mm}$ de diâmetro dos frutos da $2^{a}$ penca inferior); comprimento, diâmetro e densidade de frutos; firmeza de polpa, relação polpa/casca, $\mathrm{pH}$ da polpa e sólidos solúveis de frutos verdes. O ensacamento, independentemente da época, resultou em menor intervalo em dias entre a emergência da inflorescência e o ponto de colheita para o mercado externo; o ensacamento realizado 10 dias após a emergência da inflorescência propiciou aumento de comprimento e diâmetro dos frutos das pencas superiores e reduziu o teor de sólidos solúveis em frutos verdes. $O$ ensacamento não interferiu sobre o peso de cacho, densidade, firmeza, relação polpa/casca e $\mathrm{pH}$ dos frutos verdes. 


\title{
PROTECTION OF BUNCHES OF BANANA (Musa $s p$ AAA) IN DIFFERENT TIMES AND PERIODS AFTER INFLORESCENCE
}

\author{
Author: JOSÉ NILTON MEDEIROS COSTA \\ Adviser: Prof. Dr. JOÃO ALEXIO SCARPARE FILHO
}

\section{SUMMARY}

Two experiments were carried objectifying to evaluate the effects of the sacking of banana bunches, with polyethylene sacks, in varieties Nanicão and Grande Naine. The experiments were made in banana plantation established in Fazenda Diamante, county of Tietê - SP.

The first experiment consisted of the evaluation of the sacking of banana bunches 'Nanicão', in different times. The experimental design used randomized blocks, in factorial $2 \times 3$ with four repetitions. The sacking was done with polyethylene sacks and the studied periods were winter, summer and autumn; each period in fact was defined as the time between inflorescence and harvest, and so did not match exactly the seasons. The measured variable were: weight of the bunch; interval between inflorescence and harvest; length, diameter, density, pulp firmness, pulp to peel ratio, $\mathrm{pH}$ and soluble solids of green fruits. No significant difference was detected for the interaction saking $x$ season. It was verified that, as an effect of the sacking of the banana bunches, there was a decrease in the interval between inflorescence and harvest in winter and summer, and a fruit density of less than 1.00 for summer and autumn, smaller of soluble solids and firmness. There was not difference in to the bunch weight, length and fruit diameter, $\mathrm{pH}$ and pulp to peel ratio in green fruits. 
The second experiment objectified the evaluation of the sacking of banana bunches 'Grande Naine', in different times after the emergency of the infiorescência (10,20 and 30 days). The experimental design used randomized blocks with five replications. The analyzed variables were: weight of bunches; interval in days between inflorescence and harvest for the external market (caliber of $34 \mathrm{~mm}$ of diameter of the fruits of the 2 nd superior hand) and internal market (caliber of $34 \mathrm{~mm}$ of diameter of the fruits of the 2 nd inferior hand); length, diameter and density of fruits, density, pulp firmness, puip to peel ratio, $\mathrm{pH}$ and soluble solids of green fruits. The bagging, independently of when it took place, resulted in a smaller interval between inflorescence and the harvest point for the external market. The bagging done 10 days after inflorescence increased the length and diameter of the fruits of the $2 a$ superior hand and it reduced the soluble solids in green fruits. The bagging did not effect the bunch weight, density, firmness, pulp to peel ratio and $\mathrm{pH}$ of the green fruits. 


\section{INTRODUÇÃO}

A banana (Musa sp) é a fruta tropical mais cultivada nas regiões quentes do mundo, onde é produzida quase o ano todo. Caracteriza-se pelo alto consumo, sendo a fruta de maior volume transacionado no comércio mundial. A produção mundial alcançou cerca de 56 milhões de toneladas em 1996. A atual colocação do Brasil é a de segundo maior produtor de banana, com a produção de 5,7 milhões de toneladas por ano, equivalente a 10,2\% do total mundial (Organização das Nações Unidas para a Agricultura e Alimentação - FAO, 1996), apresentando-se como o maior consumidor dessa fruta, com o consumo de $40 \mathrm{~kg} /$ pessoa/ano ano (Moreira, 1987).

É cultivada em quase todos os estados brasileiros, desde a faixa litorânea até os planaltos do interior, embora o seu cultivo sofra restrições em função de fatores climáticos como temperatura e precipitação pluvial. Ocupa o segundo lugar entre as fruteiras, em relação à área colhida, e é cultivada em 514.060 hectares (Anuário Estatístico do Brasil, 1996).

A bananicultura brasileira apresenta caracteristicas peculiares, concernentes à diversidade climática em que é explorada, no uso de cultivares, na forma de comercialização e exigências do mercado. Adota-se o extrativismo, com baixos índices de capitalização e tecnologia, com exceções de algumas áreas nos estados de São Paulo, Santa Catarina, Goiás, Minas Gerais, Pernambuco, Bahia e Rio Grande do Norte. A produtividade média é inferior a 16 tha, devido ao porte elevado de algumas variedades, à intolerância à estiagem e à incidência de doenças e pragas (Alves, 1986). 
A realidade da bananicultura brasileira mostra uma profunda precariedade, embora o Brasil seja o segundo maior produtor mundial de banana. O volume de frutas exportadas é pouco expressivo, não ultrapassando o percentual de $1,5 \%$ do total produzido (Carraro \& Cunha, 1994).

O mercado internacional de banana é regido por um moderno complexo integrado pelo fluxo produção-consumo. A marca essencial é a qualidade do produto final, conseguida com baixos niveis de perdas e elevada produtividade dos processos. Não há como comparar mundialmente uma bananicultura colocada em plantações de agricultores de reduzida profissionalização com os modernos bananais geridos em bases empresariais, comprometidos com a qualidade do produto e consequente domínio do mercado.

Frente à característica do complexo bananeiro mundial, para que a produção brasileira de banana tenha alguma possibilidade de sucesso em termos de competitividade, exige-se uma política ativa do Governo Federal, lançando as bases da organização de uma moderna produção da fruta, que rompa com a tradição de "fruticultura extrativa" a ela associada e constitua uma ampla cadeia integrada, da produção ao consumo, para abastecer o próprio mercado interno, devido à possivel competição, com o avanço inevitável no processo de integração comercial da América Latina (Gonçalves et al., 1994).

Como se depreende da análise da bananicultura no Brasil, um dos problemas que se destaca é concernente à qualidade dos frutos produzidos, fato que certamente contribui para insignificante participação na exportação do produto

O ensacamento dos cachos de banana com filmes plásticos, no início de seu desenvolvimento na planta, pode ser uma tecnologia que venha contribuir para a melhoria de qualidade da banana produzida no Brasil. Os 
benefícios são devidos à proteção do cacho contra atritos, ataque de insetos, efeitos de baixas temperaturas ("chilling"); o aceleramento do desenvolvimento do cacho, a uniformização da coloração das bananas e a promoção de maior atratividade visual dos frutos (Heenan, 1973; Moreira, 1987; Soto Ballestero et al., 1992 e Lichtemberg, 1996).

A prática é efetuada rotineiramente nos paises da América Central; contudo, no Brasil tem sido executada em caráter experimental e, recentemente, há experiências de alguns produtores nos estados de São Paulo e Santa Catarina. Como as informações sobre a técnica são limitadas, para atender as diferentes situações (cultivares e condições climáticas) que ocorrem no Brasil, é necessário prosseguir com pesquisas que venham propiciar possiveis respostas para uma melhor e adequada utilização do ensacamento de cachos de banana.

Este trabalho foi realizado com o objetivo de avaliar os efeitos do ensacamento em cachos de banana com sacos de polietileno, nas cultivares Nanicão e Grande Naine. Estudou-se o ensacamento em diferentes épocas do ano na cv. Nanicão e períodos após a emergência da inflorescência na cv. Grande Naine. 


\section{REVISÃO DE LITERATURA}

\subsection{Classificação botânica}

As bananeiras produtoras de frutos comestiveis pertencem à classe das Monocotiledôneas, ordem Scitaminales, familia Musaceae, subfamília Musoideae, gênero Musa e seções Eumusa e Australimusa (Dantas et al., 1997).

As cultivares evoluíram, na grande maioria, a partir da espécie Musa acuminata Colla ou de hibridações entre esta espécie e Musa balbisiana Colla, ambas diplóides. As bananeiras com frutos comestiveis pertencentes à seção Eumusa têm 22, 33, ou 44 cromossomos, cujo número básico $(n=11)$ ou genômio é representado pelas letras A ( $M$. acuminata) e B ( $M$. balbisiana), de modo que as cultivares correspondentes àquele número são, respectivamente, diplóide $(A A, B B$ e $A B$ ), triplóide $(A A A, A A B$ e $A B B)$ ) tetraplóide (AAAA, AAAB, AABB e ABBB) (Simmonds \& Shepherd, 1955). As cultivares triplóides são geralmente mais numerosas e importantes economicamente, as diplóides encontram-se em menor número e as tetrapóides existem em número reduzido (Shepherd, 1984).

\subsection{Biologia do florescimento e frutificação}

Após a geração do número total de folhas e gemas laterais de brotação da planta, a gema apical cessa essa atividade, devido a uma série de fatores hormonais. Ocorre, então, a diferenciação floral, que é uma 
modificação do aspecto da gema apical e a transformação da mesma na inflorescência (Simão, 1971; Medina, 1985 e Moreira,1987).

A mudança da fase de desenvolvimento vegetativo do meristema apical para o estádio floral, três a quatro meses antes da emergência da inflorescência no ápice da planta, não pode ser definido pela simples observação, é detectado posteriormente. Existe um número constante de cerca de onze folhas (embrionárias) na gema apical, que permanecem em desenvolvimento dentro do pseudocaule (Turner, 1972 a;b; Holder \& Gumbs, 1982).

O processo da diferenciação ocorre quando cerca de $60 \%$ de todas as folhas (jovens e adultas) que a gema apical de crescimento produziu já exteriorizaram. Contudo, as folhas restantes já formadas (40\%), ainda permanecem em desenvolvimento no interior da planta (Moreira, 1987).

A diferenciação floral pode ocorrer uma vez que uma quantidade especifica de área foliar tenha sido produzida (Israeli \& Blumenfeld, 1985, citando Alexandrovicz'), embora não seja conhecido se essa diferenciação representa um particular estádio de desenvolvimento ou é decorrência de uma taxa de crescimento favorável (Marchal \& Jannoyer,1993).

Ocorrida a modificação da gema apical em inflorescência, conclui-se que, após a diferenciação floral, a bananeira não gera mais folhas. Por conseguinte, após o lançamento da inflorescência, não ocorre mais emissão de nenhuma folha (Medina, 1985 e Moreira, 1987).

O desenvolvimento da inflorescência no interior do pseudocaule tem uma duração de mais de 100 dias; e entre a diferenciação floral e a floração podem transcorrer de 45 a 90 dias (Soto Balestero \& Ruiz, 1992).

Formada a inflorescência, ocorre rápido processo vertical de caminhamento da mesma, subindo pelo centro do pseudocaule, ultrapassando

\footnotetext{
${ }^{1}$ ALEXANDROVICZ. L. Étude du developpement de l'inflorescence du bananier nain. Annales Institut des Fruits er Agrumes Colonfaux. n.9 p. 1-32. 1955.
} 
a roseta foliar para expandir-se no exterior. É determinado a uma só vez o alongamento vertical final de rizoma com a formação do palmito e do engaço, que é o pedúnculo da inflorescência (Moreira, 1987).

São encontradas na inflorescência da bananeira flores femininas e masculinas $e$, menos freqüentemente, flores hermafroditas.

As flores são definitivamente bissexuais na estrutura, porém são principalmente unissexuais na função. A flor feminina é constituida de gineceu infero, longo, trilocular, em cujo ápice encontram-se seis tépalas (cinco fundidas e uma livre), circundando o estilo espesso e os cinco ou seis estames (estaminóides) carnosos e não funcionais. A flor masculina possui ovário atrofiado, com estilo muito delgado, cujos estames são encimados por longas anteras normais e os sacos polínicos estão dispostos ao longo do filamento em duas linhas paralelas (Medina, 1985).

Além das diferenças na constituição, as flores masculinas e femininas diferem também em seu comportamento. As flores masculinas sofrem abscisão a partir da base do ovário abortivo e se desprendem completamente depois de haver estado expostas em torno de um dia. As flores femininas não têm estrato de abscisão na base do ovário, que, portanto, é sempre persistente; nelas o perianto, o estilo e os estaminóides sofrem abscisão, deixando na parte superior do ovário uma cicatriz calosa, que persiste como aspecto característico do fruto adulto da bananeira (Simmonds, 1973).

A inflorescência é descrita como um espiga simples e terminal porque é desenvolvida de uma gema apical (Medina, 1985).

As flores desenvolvem-se sobre almofadas rasas, as quais circundam parcialmente a gema apical, são arranjadas em pencas, estas seqüenciadas em duas linhas alternadas. As pencas florais, subentendidas como brácteas comuns, são arranjadas no sentido horário (da base para 
inflorescência) em sucessão espiralada. Na parte basal da inflorescência existem 5-15 pencas femininas (Simmonds, 1973).

As pencas de flores hermafroditas (1-2) podem ocorrer seguidas de muitas pencas de flores masculinas (Ram et al., 1962). O número de pencas femininas e de flores femininas numa inflorescência varia consideravelmente em diferentes espécies, cultivares e condiçōes ambientais (Simmonds, 1973). O número de flores femininas em cada penca diminui gradualmente em uma seqüência acropétala, exceto na primeira penca basal, o qual é altamente variável, em que às vezes aparecem menos flores do que na segunda. O comprimento dos internódios da parte feminina da inflorescência diminui, também, da base ao ponto distal (Champion, 1975).

$\mathrm{Na}$ região de transição entre flores femininas e flores masculinas é possivel encontrar os dois sexos em uma mesma penca; e mesmo, pencas de flores hermafroditas intercaladas com as masculinas, após o aparecimento de todas as flores femininas (Moreira, 1987).

As bananeiras de frutos comestiveis geralmente não produzem grãos de pólen férteis; e os ovários das flores femininas dificilmente são fecundados, devido a um atrofiamento do estigma, que impede a passagem do pólen. Há casos, porém, de não atrofiamento e a fecundação poderá se processar normalmente $e$, mediante este acontecimento, surgirem sementes férteis (Simmonds, 1973).

Os frutos comestiveis são oriundos de partenocarpia vegetativa, isto é, sem polinização. No início, o ovário cresce em comprimento e diâmetro. O tecido do pericarpo (parede do ovário) que está sobre os lóculos se invagina sobre os mesmos; o eixo floral, a placenta e os septos se dividem mitoticamente e se expandem. Ao final toda a cavidade ovárica está completamente extinta e a porção central do fruto fica constituida por um tecido carnoso e suave, a massa de polpa comestivel (Soto Ballestero \& Ruiz, 1992). 
A fisiologia do desenvolvimento partenocárpico da banana é regulada aparentemente por uma produção endógena de auxina no ovário adulto. A atividade das substâncias do crescimento no fruto não foi ainda plenamente elucidada, mas parece patente que, na fruta partenocárpica, um estímulo autônomo ao crescimento substitui o estímulo que, em bananeira seminifera, se deriva das sementes em desenvovimento (Simmonds, 1973).

Conforme Dantas et.al. (1997), o cacho da bananeira é constituido de engaço, ráquis, pencas, frutos e botão floral (coração).

O engaço, botanicamente, é o pedúnculo da inflorescência, tendo início no ponto de fixação da última folha e terminando na inserção da primeira penca.

O ráquis é definido botanicamente como eixo de uma inflorescência, sendo nele que se inserem as flores. Inicia-se a partir do ponto de inserção da primeira penca e termina no botão floral. Pode ser dividido em ráquis feminino, onde se inserem as flores femininas, e ráquis masculino, onde se inserem as flores masculinas (Medina, 1985 ).

Botão floral ou coração é o conjunto de flores masculinas ainda em desenvolvimento, com suas respectivas brácteas. Pode-se dizer que 0 coração é a gema apical de crescimento, modificada, que ganhou o exterior.

Pencas é o conjunto de frutos, reunidos pelos seus pedúnculos em duas fileiras horizontais e paralelas. O ponto de fusão dos pedúnculos recebe o nome de almofada. As almofadas se fixam no ráquis sempre em níveis diferentes, seguindo três linhas helicóides e paralelas (Moreira, 1987).

O comprimento e diâmetro do cacho, o número e tamanho de frutos e pencas variam conforme a cultivar, o clima, a fertilidade do solo, os tratos culturais e fitossanitários (Moreira, 1987 e Stover \& Simmonds, 1987). Em condições edafoclimáticas e de condução adequadas, estas variações não são tão acentuadas quando trata-se de médias referentes a cachos de uma mesma cultivar (Moreira, 1987). 
Marchal \& Jannoyer (1993) afirmam que a produção de banana pode ser definida pela combinação de quatro componentes: i) número de folhas/bananeira/unidade de área; ii) número de pencas (extrato floral) por cacho; iii) número de frutos (flores femininas por penca); iv) peso médio dos frutos.

\subsection{Ciclos da bananeira}

A bananeira como todas as plantas, tem um ciclo de vida definido que se inicia com a formação do rebento e seu aparecimento em nivel do solo. Com seu crescimento há a formação da planta, que irá poduzir um cacho cujos frutos se desenvolvem, amadurecem e caem, verificando-se em seguida o secamento de todas as suas folhas, culminando com sua morte.

De uma maneira prática, definem-se em dois os ciclos da bananeira: o ciclo vegetativo e o ciclo de produção. Define-se o ciclo vegetativo como o período compreendido entre o aparecimento do rebento (ou perfilho) na superfície do solo e a colheita de sua produção. O ciclo de produção é o intervalo de tempo que decorre entre a colheita do cacho de uma bananeira e a colheita do cacho do seu "filho" (Moreira, 1987).

Tanto um ciclo como outro são afetados por todos os fatores edafoclimáticos e técnicas culturais, além da idade do próprio bananal e da cultivar plantada. Bananais com mais de três safras, com densidades elevadas e em condições de clima e solo desfavoráveis, como também de manejo, podem ter os citados ciclos aumentados de até mais do dobro, com graves prejuizos de produtividade e, portanto, na economia dessa atividade agrícola (Medina, 1985)

\subsection{Proteção de cachos de banana na planta com sacos de polietleno}

Em países tropicais e subtropicais onde a bananicultura é desenvolvida, o uso da cobertura de cachos com polietileno é virtualmente 
universal, sendo atualmente considerada como uma técnica essencial para melhorar o rendimento e qualidade dos cachos de banana (Robinson, 1995).

De acordo com Turner e Rippon (1973); Daniells et al. (1987) e Johns \& Scott (1989); o ensacamento dos cachos com filmes plásticos, no início de seu desenvolvimento, na planta, propicia aumento do tamanho final do fruto. Outros benefícios auferidos pela técnica são a proteção contra o frio, ação abrasiva das folhas e ataque de insetos, como também a melhoria da qualidade visual dos frutos, tornando-os mais atrativos ao consumidor (Heenan, 1973; Moreira, 1987 e Soto Ballestero et al., 1992).

Outra vantagem do ensacamento é a redução do período entre a emergência da inflorescência e a colheita $(E-C)$. A maioria dos pesquisadores encontraram um intervalo mais curto para cachos ensacados, comparados com os não ensacados (Berril, 1956; Perumal \& Adam, 1968; Turner \& Rippon, 1973 e Daniells et al., 1987). Robinson \& $\mathrm{Nel}$ (1984) não encontraram diferenças, enquanto que Scott et al. (1971) verificaram um maior intervalo para os cachos ensacados.

A redução do período $\mathrm{E}-\mathrm{C}$ foi verificado em cachos ensacados e abertos em suas extremidades inferiores (Perumal \& Adam, 1968; Daniells et al., 1987 e Daniells et al., 1992). Quando mantidos totalmente fechados, ocorreu atraso no desenvolvimento dos cachos (Scott et al., 1971; Johns \& Scott, 1989 e Daniells et al, 1992) e o retardamento da maturação pós-colheita dos frutos (Scott et al., 1971 e Johns \& Scott, 1989), fatos associados à redução do teor de oxigênio e aumento dos teores de gás carbônico e etileno no interior das embalagens.

Sampaio \& Simão (1970) verificaram a ocorrência de queimaduras ocasionadas pela luz solar, em cachos cujos sacos foram amarrados apenas nas extremidades inferiores. Segundo os autores, as queimaduras foram decorrentes da associação da exposição dos cachos à luz solar, devido às condições desfavoráveis nesta estação para o 
desenvolvimento vegetativo das plantas, e ao engaço curto, característico na cultivar Nanica.

A ocorrência de queimaduras dos frutos pela ação dos raios solares e o escurecimento das paredes dos septos que envolvem as cavidades ovarianas é mais acentuada quando os sacos são fechados em ambas extremidades (Salomão, 1995).

Em condições de clima subtropical, como na África do Sul, na Austrália (Nova Gales do Sul) e no Brasil (Santa Catarina), o cacho de banana do subgrupo Cavendish pode permanecer na planta por até sete meses, nos períodos frios. Nestas condições climáticas, o ensacamento dos cachos apresenta as seguintes vantagens adicionais: redução dos danos causados pela incidência de ventos frios; diminuição dos prejuízos provocados pela ocorrência de baixas temperaturas, "friagem" ou "chilling"; melhora da coloração (mais clara), elasticidade e espessura da casca, reduzindo o rachamento (casca "vitrificada"), melhorando o aspecto do fruto (Robinson, 1995 e Lichtemberg, 1996).

Para as condições de climas subtropicais, ainda podem ser acrescentadas, como vantagens indiretas, a melhoria na climatização da banana, que no Sul do Brasil é difícil e de baixa qualidade, entre os meses de outubro a dezembro; e redução na densidade dos frutos, o que evita ou reduz - afundamento das bananas nos tanques de lavagem na pós-colheita (Lichtemberg, 1996).

Problemas e desvantagens do ensacamento dos cachos na lavoura também são verificados, destacando-se o aumento do custo de produção, pela compra dos sacos plásticos e fitilhos para amarração e pelo pagamento da mão-de-obra adicional para a execução da prática; a produção de frutos com a casca mais frágil; a dificuldade de realizar a prática em bananeiras de porte alto; o aumento na persistência dos restos florais; a dificuldade na visualização dos frutos e, conseqüentemente, a verificação do 
ponto de colheita; o aumento do risco de poluição ambiental; o aumento na incidência da "ponta do charuto" (Verticilium teobromae (Turc.) Mason \& Hughes); queimaduras ocasionadas pelos raios solares e a dificuldade de uso do ensacamento em bananais de encostas (Lichtemberg, 1996).

Conforme Salomão (1995), o ensacamento de cachos com plástico durante o desenvolvimento faz aumentar a proporção de polpa do fruto, dada pela relação polpa/casca.

Frutos ensacados com embalagem plástica durante 0 desenvolvimento na planta apresentam amadurecimento retardado após a colheita, quando comparados com frutos não ensacados (Scott et al, 1971; Salomão, 1995)

De acordo com Soto Ballestero et al. (1992), os principais aspectos a serem considerados em relação ao uso do polietileno para efeito de proteção de cachos de banana na planta são a época de colocação do saco, dimensões do saco e práticas que antecedem o ensacamento (eliminação do coração e despistilagem).

O ensacamento deve ser efetuado o mais cedo possivel, a fim de que se usufrua dos benefícios da prática por mais tempo. Recomenda-se, geralmente, realizar esta prática quando o cacho tem emitido a última bráctea, ou seja, quando a última penca verdadeira apresenta os frutos iniciando a volta para cima (Soto Ballestero et al., 1992).

Anteriormente à colocação do saco procede-se à retirada do coração e despistilagem. A extremidade distal do ráquis floral masculino deve ser quebrada de 12 a $15 \mathrm{~cm}$ de distância do ponto de inserção da última penca feminina e descartada (Moreira, 1987). Após a colocação, os sacos são fechados nas extremidades proximais dos cachos, deixando-se a extremidade inferior do saco aberta, para evitar excesso de umidade e acúmulo e putrefação de resíduos. O saco plástico deve ultrapassar em 15 a $30 \mathrm{~cm}$ a última penca remanescente do cacho (Lichtemberg, 1996). 
O polietileno usado para confecção dos sacos deve ser de baixa densidade. Os sacos devem ser perfurados para evitar o excesso de umidade e a proliferação de pragas e doenças, principalmente fungicas, como por exemplo a fumagina ( Capnodium sp.) (Lichtemberg, 1996).

Geralmente são utilizados sacos perfurados de coloração azul, nas dimensões de 1,55 a 1,60 m de comprimento por 0,70 a $0,81 \mathrm{~m}$ de largura e $0,08 \mathrm{~mm}$ de espessura, com furos de 12,5 a $12,7 \mathrm{~mm}$ de diâmetro, distribuídos em quadrados a cada $76 \mathrm{~mm}$. Também são empregados sacos com furos de $3 \mathrm{~mm}$ de diâmetro, em quadro a cada $12,5 \mathrm{~mm}$ (Soto Ballestero et al., 1992).

Coberturas azuis translúcidas são preferiveis, pois permitem a transmissão de calor, reduzem os danos causados por queimaduras do sol e permitem a realização de avaliação visual do cacho em desenvolvimento (Robinson, 1995).

Os estudos abordados motivam a utilização do ensacamento, desde o início do desenvolvimento do fruto, na planta, cujas vantagens quanto à produção, qualidade e aspecto externo dos frutos têm sido apontadas no prolongamento do período pré-climatérico. As informações sobre os processos fisiológicos envolvidos e sobre a qualidade do produto são, contudo, ainda escassas para permitir a recomendação da técnica com segurança (Salomão, 1995).

\subsection{Colheita}

A colheita apresenta como principais objetivos a retirada do produto do campo em niveis adequados de maturidade, com um mínimo de danos ou perdas, com a maior rapidez possivel e com um custo mínimo. Após a colheita, o produto é geralmente manuseado de forma rudimentar, o que the acarreta injúrias físicas, as quais, posteriormente, resultam em deteriorações fisiológicas e patológicas (Chitarra \& Chitarra, 1990). 
Antes da colheita, é necessário determinar o estádio de maturação em que a fruta se encontra, pois a colheita realizada em momento inadequado, fora do ponto ideal, pode influenciar não só a produção, em termos de volume colhido por área, como também no comportamento das frutas em pós-colheita, tanto na fase de amadurecimento controlado como na comercialização. Os cuidados com o transporte, embalagem e nos tratamentos pós-colheita também podem ser influenciados pelo estádio de maturação da fruta no momento da colheita (Simão, 1971).

Existem basicamente dois tipos de maturação ou maturidade: a maturação fisiológica e a maturação horticultural ou comercial (ou amadurecimento). A maturação fisiológica corresponde àquela em em que o fruto atingiu seu tamanho e peso máximo, porém ainda não possui características visíveis e sensoriais desejáveis de consumo. Mesmo esse fruto sendo destacado da planta ele continua a sua ontogenia e atinge, posteriormente, a maturidade horticultural, que corresponde ao estádio de desenvolvimento em que o fruto possui os pré-requisitos para ser consumido (Watada et al., 1984)

Em bananas, normalmente, a colheita é realizada quando essas atingem a maturação fisiológica, com a maturação comercial sendo alcançada posteriomente, através de amadurecimento artificial. Essa prática é possível graças ao fato da banana ser uma fruta que apresenta o periodo climatérico. $O$ climatérico corresponde a uma fase, dentro do processo de maturação, em que há um súbito aumento na taxa respiratória, desencadeada pelo hormônio etileno $\left(\mathrm{C}_{2} \mathrm{H}_{4}\right)$, conduzindo a uma série de transformações que elevam as qualidades visuais e sensoriais das frutas (Bleinroth, 1985 e Chitarra \& Chitarra, 1990)

A determinação do ponto de colheita, na prática, é muito influenciada pela experiência do produtor, o qual, invariavelmente, através de avaliações a "olho nu", reconhece o melhor momento de iniciar a colheita dos 
cachos. O desaparecimento das quinas dos frutos pode ser utilizado como referencial para a colheita dos cachos em sua maturidade fisiológica, principalmente em cultivares como 'Nanica', 'Nanicão', 'Maçã' e 'Prata'. Porém, para outros cultivares ('Terra', 'São Tomé', Figo' e 'Marmelo') esse indicador de maturação é problemático, uma vez que as quinas dos frutos permanecem salientes, mesmo quando esses atingem a sua maturidade fisiológica. Neste caso deve-se proceder à colheita quando os frutos localizados no meio do cacho apresentarem desenvolvimento máximo de seu diâmetro (Bleinroth, 1985; Reid, 1992; Alves \& Oliveira, 1995).

Bleinroth (1972) e Medina (1985) classificaram os estádios de maturação da banana quanto ao diâmetro e angularidade dos frutos, medida através de cortes transversais nos mesmos, da seguinte maneira:

- estádio magro (30 mm de diâmetro): bananas com quinas salientes e superfície estreita e plana;

- estádio $3 / 4$ magro (32 mm): bananas com quinas salientes e superfície estreita e plana;

- estádio $3 / 4(34 \mathrm{~mm})$ : bananas ainda com presença de quinas, porém os lados são mais largos e ligeiramente arredondados;

- estádio $3 / 4$ gordo ( $36 \mathrm{~mm}$ ): bananas não apresentam quinas e as faces são arredondadas;

- estádio gordo (38 mm): bananas cheias e completamente arredondadas.

Segundo esses mesmos autores, a escolha do ponto de colheita, baseado nos citados estádios depende do destino a que pretende dar a fruta e das condições climáticas. Os autores preconizam que, na estação quente; os cachos podem ser colhidos em estádios mais avançados $(3 / 4$ gordo e gordo), quando as frutas são destinadas para mercados próximos, e em condições de maturação menos avançada $\left(3 / 4\right.$ magro $\left.e^{3} / 4\right)$, para mercados mais distantes. $\mathrm{Na}$ estação fria, a colheita deve ser realizada nos estádios $3 / 4$ gordo e gordo, independente da distância de mercado. 
Bleinroth (1985) indica ainda que bananas destinadas a desidratação (banana passa) devem ser colhidas no estádio $3 / 4$ magro, apresentando 30 e 32mm de diâmetro, para os cultivares 'Nanica' e 'Nanicão', respectivamente.

Quando destinadas para exportação, as bananas devem ser colhidas no estádio $3 / 4$, com $32 \mathrm{~mm}$ para 'Nanica' e $34 \mathrm{~mm}$ para 'Nanicão'.

\subsection{Amadurecimento e transformações bioquímicas em banana}

O início do amadurecimento de frutos climatéricos, como a banana, é marcado por um rápido aumento da taxa respiratória, desencadeado pelo aumento na sintese endógena do hormônio etileno $\left(\mathrm{C}_{2} \mathrm{H}_{4}\right)$. A taxa respiratória aumenta até um nivel máximo (pico climatérico) e posteriormente declina, com o avanço do amadurecimento. Durante este processo, várias modificações ocorrem nos frutos, tais como: amaciamento da polpa, conversão de amido em açúcares simples, destruição da clorofila (cor verde) e sintese elou aparecimento de carotenóides (cor amarela), perda de adstringência e desenvolvimento de sabor e aroma característicos (Palmer, 1971; Thompson \& Burden, 1995).

As modificações citadas são governadas, segundo Palmer (1971), por fatores genéticos, pelo aumento na permeabilidade das membranas celulares e pela elevação na atividade enzimática. Marriot (1980) aponta, como principal modificação que ocorre em bananas durante o amadurecimento, a transformação do amido em açúcares. O autor salienta que o fruto fisiologicamente maduro é constituído, em termos de peso seco, por cerca de $88 \%$ de amido. Com o amadurecimento, este teor cai para 5 a $15 \%$, enquanto que os açúcares solúveis (sacarose, frutose, e glicose) alcançam de 70 a $80 \%$ do peso seco.

Sgarbieri \& Figueiredo (1971) estudando as transformações bioquímicas da banana 'Nanica' (teores de sólidos solúveis, acidez orgânica, 
ácido ascórbico, ácidos graxos e carboidratos) amadurecidas sob diferentes condições, concluiram que as mudanças mais sensiveis observadas foram em relação aos teores de sólidos solúveis, que aumentam rapidamente à medida que a fruta amadurece, e ao amido, que se transforma quase que quantitativamente em açúcares solúveis, durante o amadurecimento. 

AAA), COM SACOS DE POLIETILENO, EM ÉPOCAS DISTINTAS

\subsection{RESUMO}

Buscou-se neste trabalho avaliar o efeito do ensacamento de cachos de banana em diferentes épocas sobre a cultivar Nanicão. O experimento foi conduzido em bananal situado na Fazenda Diamante, Municipio de Tietê - SP. Empregou-se o delineamento em blocos ao acaso, em fatorial $2 \times 3 \mathrm{com}$ quatro repetições. O ensacamento foi efetuado com sacos de polietileno e as épocas estudadas foram inverno, verão e outono, definidas pela ocorrência do ciclo completo da estação no intervalo compreendido entre a emergência da inflorescência e a colheita. As variáveis medidas foram: intervalo em dias entre a emergência da inflorescência e a colheita; peso do cacho; comprimento, diâmetro e densidade do fruto; firmeza de polpa, relação polpa/casca, pH e sólidos solúveis de frutos verdes. Para a interação ensacamento $x$ épocas não foi detectada diferença significativa para nenhuma das variáveis. Verificaram-se, como efeitos do ensacamento dos cachos, o decréscimo do intervalo entre a emergência da inflorescência e a colheita no inverno e verão, densidades menores que 1,00 no verão e outono e menor teor de sólidos solúveis e firmeza. Não houve diferença em relação ao peso de cacho, comprimento e diâmetro de fruto; $\mathrm{pH}$ e relação polpa/casca em frutos verdes. 


\subsection{Summary: PROTECTION OF BANANA BUNCHES OF THE VARIETY NANICÃO (MUSa sp AAA), WITH POLYETHYLENE BAGS DURING DIFFERENT TIMES OF YEAR}

This work evaluated the effect of bagging bunches of bananas of the variety Nanicão. The experiment was carried out on the banana plantation of the Fazenda Diamante, in the county of Tietê - SP. The experimental design used randomized blocks, in factorial $2 \times 3$ with four repetitions. The bagging was done with polyethylene bags and the studied periods were winter, summer and autumn; each period in fact was defined as the time between inflorescence and harvest, and so did not match exactly the seasons. The measured variable were: weight of the bunch; interval between inflorescence and harvest; length, diameter, density, pulp firmness, pulp-to-peel ratio, $\mathrm{pH}$ and soluble solids of green fruits. No significant difference was detected for the interaction bagging $x$ season. It was verified that, as an effect of the bagging of the banana bunches, there was a decrease in the interval between inflorescence and harvest in winter and summer, a fruit density of less than 1.00 for summer and autumn, reduction of soluble solids and firmness. There was no difference in $\mathrm{pH}$ and pulp-to-peel ratio in green fruits.

\subsection{INTRODUÇÃO}

Embora o Brasil seja o segundo maior produtor mundial de banana, sua participação no mercado exportador é insignificante, não ultrapassando o percentual de $1,5 \%$ do total produzido (Carraro \& Cunha, 
1994). Isto deve-se ao elevado consumo interno, cerca $40 \mathrm{~kg} / \mathrm{pessoa} / \mathrm{ano}$ (Moreira,1987) e à qualidade inadequada do fruto para exportação.

Os mercados de exportação de bananas do Brasil são a Argentina e o Uruguai. A transação comercial já é pouco expressiva e ainda se verifica a perda na participação do mercado argentino, que tem passado a importar do Equador, devido à melhor qualidade dos frutos.

As perspectivas de recuperar este mercado e ampliar seus negócios com os paises citados, aliado ao fato de que o Mercosul apresentase como uma expectativa de mercado sólido e rentável, determinam que o Brasil passe a investir em tecnologia de produção, sob o risco de declinar de sua já modesta cota no mercado (Scarpare Filho, 1996).

Gonçalves et al. (1994) salientam sobre a dificuldade de comparar, em nivel global, a bananicultura desenvolvida no Brasil, com a atividade conduzida em bases empresariais, como acontece em outros países, onde há o comprometimento com a qualidade do produto e o conseqüente domínio do mercado.

A situação pode ser revertida, mediante uma política federal que resulte na organização de uma moderna produção da fruta, rompendo com a tradição de "fruticultura extrativa" a ela associada. Deve ser constituída uma ampla cadeia integrada da produção ao consumo, para abastecer o próprio mercado interno, como alternativa a possivel competição, que surgirá com o processo de integração comercial da América Latina.

Como se depreende da análise da bananicultura no Brasil, um dos problemas que se destaca é concernente à qualidade dos frutos produzidos, fato que certamente contribui para insignificante participação na exportação do produto.

O ensacamento dos cachos com filmes plásticos, no início de seu desenvolvimento na planta, pode ser uma tecnologia que venha contribuir para a melhoria de qualidade da banana produzida no Brasil. Os benefícios são 
devidos ao aumento do peso de cachos; à redução do intervalo entre a emergência da inflorescência e a colheita (E-C); melhoria visual dos frutos, tornando-os mais atrativos para o consumidor; aumento do tamanho final do fruto; proteção contra o frio, ação abrasiva das folhas e ataque de insetos (Heenan, 1973; Soto Ballestero et al., 1992; Lichtemberg, 1996).

Por muitos anos, pesquisadores têm afirmado que rendimento $e$ qualidade de cachos desenvolvidos no inverno são melhores quando ensacados. As elevações de produtividade são atribuídas ao aumento de peso, à redução do intervalo entre a emergência da inflorescência e a colheita, ou ambos (Robinson, 1995).

$O$ efeito sobre a redução do intervalo entre a emergência da inflorescência e a colheita e o aumento na produção nem sempre estão em concordância com os resultados obtidos em diferentes pesquisas realizadas com proteção de cachos em bananeiras.

Em relação ao peso do cacho, foram registrados em bananas 'Dwarf Cavendish' aumentos de 25\% por Cann (1965) em Nova Gales do Sul (Austrália), e 16,7\% na África do Sul por Robinson \& Nel (1984). Em três localidades diferentes do Vale do Aridane (IIhas Canárias), caracterizadas por apresentarem altitudes diversas, Galán Saúco et al. (1996) verificaram em 'Dwarf Cavendisch' aumentos de $8,7 \%, 14,2 \%$ e $18,2 \%$ no peso do cacho, sendo que os dois maiores valores foram significativos e correspondem às localidades de média e alta altitude, respectivamente. Em contraste, em experimentos conduzidos por Sampaio \& Simão (1970), Daniells et al. (1992) e Salomão (1995), com as cultivares Nanica, Williams e Mysore, respectivamente, não foram encontradas diferenças para o peso de cachos ensacados e não ensacados.

Quanto ao intervalo E-C, a maioria dos pesquisadores encontraram um intervalo mais curto para cachos ensacados, comparados com os cachos não ensacados (Berril, 1956; Turner \& Rippon, 1973 e Daniells et 
al., 1987). Robinson \& $\mathrm{Nel}$ (1984) não encontraram diferenças, enquanto que Scott et al. (1971) verificaram um maior intervalo para os cachos ensacados.

As contradições apresentadas em relação ao intervalo entre a emergência da inflorescência e a colheita, podem ser explicadas pelos diferentes critérios para definição do ponto de colheita, nem sempre considerados como um grau de calibração, mas como uma determinação subjetiva. Também pode ser conseqüência dos diferentes tratamentos, como a utilização de sacos abertos ou fechados na extremidade distal dos cachos (Galán Saúco et al.,1996).

Poucas informações existem sobre as transformações bioquimicas de frutos de cachos ensacados, em comparação com frutos de cachos não ensacados. Salomão (1995) constatou, na cultivar Mysore, que o ensacamento proporcionou aumento na relação polpa/casca; maior teor de amido e menor firmeza de polpa nos estádios iniciais da maturação.

O ensacamento de cachos com filmes de polietileno é prática efetuada em muitas outras regiões produtoras de banana do mundo (Soto Ballestero,1992 e Galán Saúco et al.,1996), sendo há vários anos procedida rotineiramente em bananais cultivados pelas grandes empresas agrícolas em países da América Central (Moreira, 1987), e cujo fato já era mencionado na década de 60 por Perumal \& Adam (1968). Contudo, no Brasil, tem sido executada em caráter experimental e, recentemente, tem crescido a adoção desta tecnologia por alguns produtores nos estados de São Paulo e Santa Catarina.

Como as informações sobre a técnica são limitadas para atender as diferentes situações (cultivares utilizadas e condições climáticas) que ocorrem no Brasil, urge desenvolver pesquisas que venham propiciar possiveis respostas para uma melhor e adequada utilização do ensacamento de cachos de banana. 
Pretendeu-se com este trabalho avaliar o efeito do ensacamento de cachos em diferentes épocas, em bananas 'Nanicão', avaliando-se a produção, em termos quantitativos e qualitativos e o intervalo entre a emergência da inflorescência e a colheita.

\subsection{MATERIAL E MÉTODOS}

\subsubsection{Local do experimento}

$\mathrm{O}$ experimento foi instalado em bananal de propriedade do $\mathrm{Sr}$. João José Pascoal, localizado na Fazenda Diamante, Município de Tietê - SP, cuja posição geográfica está definida pelas coordenadas de $23^{\circ} 07^{\prime}$ latitude sul e $47^{\circ} 43^{\prime}$ longitude oeste. A cultivar que constituiu o ensaio foi Nanicão. $O$ bananal foi estabelecido no espaçamento de $2,10 \times 2,40 \mathrm{~m}$ e estava, na ocasião da instalação do experimento, com três anos de idade. $O$ experimento foi instalado em 21/05/95.

\subsubsection{Tratamentos}

Os fatores em estudo foram:

\section{A - Ensacamento}

Ensacado = proteção dos cachos com saco de polietileno .

Não ensacado = cacho sem proteção.

B - Épocas

E1 - Inverno

E2 - Verão

E3 - Outono

Os períodos de condução para cada época estudada foram: E1 21/05/96 a 21/10/96; E2 - 17/12/96 a 20/03/97 e E3 - 26/02/97 a 02/07/97. Verifica-se que em cada uma das épocas aconteceu o ciclo completo de uma estação. Por essa razão adotou-se o nome da estação para caracterizar a 
época de avaliação dos tratamentos, embora estes tenham sido aplicados um pouco antes do iń́cio da estação definida e tenha ocorrido intervalo de tempo entre a emergência da inflorescência e a colheita que excede o período de uma estação, como aconteceu no inverno e outono.

Anteriormente à instalação do ensaio foi efetuado um estudo de homogeneidade das plantas, objetivando selecioná-las quanto ao número de pencas e tamanho do cacho. Determinou-se como padrão a seleção de bananeiras de cachos com sete pencas. O número estabelecido foi em função da ocorrência de maior percentual de plantas que apresentavam esta caracteristica.

Conforme a casualização das parcelas, os cachos selecionados para o ensacamento foram envolvidos com sacos plásticos de coloração azul, nas dimensões de $1,45 \mathrm{~m}$ de altura por $0,74 \mathrm{~m}$ de largura e $0,08 \mathrm{~mm}$ de espessura, com furos de $10,0 \mathrm{~mm}$ de diâmetro, distribuídos em quadrados a cada $85 \mathrm{~mm}$.

Anteriormente à colocação do saco procedeu-se à retirada do coração e a despistilagem nos cachos de ambos tratamentos. A extremidade distal do ráquis floral masculino foi quebrada a distância de 10 a $12 \mathrm{~cm}$ do ponto de inserção da última penca feminina e descartada, segundo recomendação de Moreira (1987). Os sacos foram fechados nas extremidades proximais dos cachos, conforme metodologia preconizada por Soto Ballestero et al. (1992).

\subsubsection{Variáveis analisadas}

a) Intervalo entre a emergência da inflorescência e a colheita ( $E$ C) - estabeleceu-se como limite para este intervalo o calibre de $34 \mathrm{~mm}$ nos frutos da $2^{a}$ penca inferior, devido a ser equivalente, nas condições do experimento, ao ponto de colheita para o mercado interno, quando as bananas 
podem ser colhidas em estádio mais avançado (Bleinroth, 1985 e Moreira, 1987).

b) Peso do cacho $(\mathrm{kg})$ - pesagem do cacho efetuada em balança marca Filizola com capacidade de $150 \mathrm{~kg}$.

c) Comprimento médio de frutos $(\mathrm{cm})$ da $2^{\mathrm{a}}$ penca superior - esta penca foi considerada como representativa do cacho, para efeito de uniformização de amostras (Carvalho et al. 1989 e Galán Saúco et al., 1996). As medições foram feitas com trena metálica flexivel, na face côncava das bananas.

d) Diâmetro médio de frutos $(\mathrm{mm})$ da $2^{\mathbf{a}}$ penca superior medições feitas com paquímetro na região central dos frutos, perpendicularmente ao maior eixo.

e) Densidade de frutos $\left(\mathrm{g} / \mathrm{cm}^{3}\right)$ - foram pesados três buquês com seis frutos verdes por repetição, os quais foram imersos em recipiente contendo água, para determinação do volume dos frutos, mediante o deslocamento da água. A densidade foi estabelecida pelo quociente massa/volume.

f) Firmeza de frutos verdes - medida pela resistência ao penetrômetro FT 327 , no terço distal do fruto.

g) Relação polpa/casca de frutos verdes - obtida mediante pesagem de polpa e casca de frutos amostrados para esse fim.

h) $\mathrm{pH}$ de frutos verdes - medido através de peagâmetro marca DIGIMED, modelo DMPH-2, usando-se uma amostra de cada repetição, segundo metodologia preconizada pelo INSTITUTO ADOLFO LUTZ (1985).

i) Teor de sólidos solúveis (SS) de frutos verdes - determinado segundo metodologia recomendada por Harman \& Watkins (1981). Uma porção de polpa de cada amostra foi colocada sobre o prisma de um refratômetro de mesa marca $A B B E$ e a leitura feita em ${ }^{\circ}$ Brix, com correção da temperatura para $20^{\circ} \mathrm{C}$. 


\subsubsection{Preparo dos frutos para análise}

Para avaliação das variáveis densidade, $\mathrm{pH}$, firmeza, teor de sólidos solúveis e relação polpa/casca, os frutos foram amostrados da segunda à quarta pencas proximais de cada cacho (Salomão, 1995). Os cachos foram colhidos quando os frutos da fileira distal da segunda penca inferior atingiram o diâmetro de $34 \pm 1 \mathrm{~mm}$, medidos em suas regiões equatoriais. O ponto de colheita guardou relação com a prática adotada para 0 comércio interno, em razão dos frutos apresentarem equivalência nas condições do experimento.

Os cachos foram colhidos, pesados e despencados pela manhã. As pencas selecionadas foram transportadas de imediato para as avaliações referentes ao comprimento, diâmetro e densidade de frutos, as quais foram executadas em Laboratório do Departamento de Horticultura da Escola Superior de Agricultura "Luiz de Queiroz" (ESALQ), em Piracicaba, São Paulo.

Para as avaliações de $\mathrm{pH}$, sólidos solúveis, firmeza e relação polpa/casca foram utilizados seis frutos verdes de cachos correspondentes às parcelas do experimento. As determinações foram efetuadas em laboratório do Centro de Energia Nuclear na Agricultura (CENA), em Piracicaba, São Paulo.

\subsubsection{Delineamento experimental}

Empregou-se o delineamento em blocos ao acaso, em fatorial $2 x$ $3 \mathrm{com}$ quatro repetições. Cada parcela foi composta por três plantas. Os fatores estudados foram ensacamento (ensacado e não ensacado) e três épocas (inverno, verão e outono).

\subsubsection{Análise estatística}

Os dados obtidos a partir das avaliações foram submetidos a análise de variância, através do Sistema SANEST, aplicando-se o teste $\mathrm{Fe}$ procedendo-se o detalhamento da análise pelo teste de Tukey, para amostras 
independentes de fatores qualitativos (melhor/pior ensacamento, melhor/pior época, melhor/pior combinação).

\subsection{RESULTADOS E DISCUSSÃO}

\subsubsection{Intervalo entre a emergência da inflorescência e a colheita (E-C)}

De acordo com os resultados obtidos, o intervalo entre a emergência da inflorescência e a colheita ( $E-C)$ não apresentou diferença significativa quanto a interação ensacamento $x$ épocas, no entanto, diferiu em relação aos fatores ensacamento e épocas, conforme se verifica na Tabela 1.

Em relação à época, como era esperado para E-C, o intervalo médio foi maior no inverno (176 dias), menor no verão (115 dias) e intermediário no outono (153 dias). A Figura 1 ilustra estes resultados.

Tabela 1 - Intervalo médio em dias entre a emergência da inflorescência e a colheita (E-C), em função dos fatores ensacamento e épocas em banana 'Nanicão'. Tietê - SP, 1997.

\begin{tabular}{lcccc}
\hline & \multicolumn{3}{c}{ ÉPOCAS } \\
\cline { 2 - 4 } TRATAMENTOS & INVERNO & VERÃO & OUTONO & MÉDIAS \\
\cline { 2 - 4 } & \multicolumn{3}{c}{ E-C (dias) } \\
\cline { 2 - 4 } ENSACADO & 171 & 109 & 153 & $144 \mathrm{~b}$ \\
NÃO ENSACADO & 180 & 120 & 153 & $151 \mathrm{a}$ \\
\hline MÉDIAS & $176 \mathrm{~A}$ & $115 \mathrm{C}$ & $153 \mathrm{~B}$ \\
\hline CV (\%) = 4,88 & DMS (5\%)*: $1=8,62 ; 2=7,44 ; 3=4,98$ \\
Médias seguidas de mesmas letras minúsculas nas colunas e maiúsculas nas linhas, não \\
diferem entre si pelo teste de Tukey em nivel de 5\%. \\
*1-médias de ensacamento dentro das épocas; 2-médias de época; 3-médias de ensacamento.
\end{tabular}


O teste de Tukey detectou diferença entre ensacado e não ensacado no inverno e no verão, ocorrendo uma redução do intervalo (E-C) para cachos ensacados de 9 e 11 dias, respectivamente (Tabela 1). Os resultados estão de acordo com aqueles obtidos por Berril (1956), Perumal \& Adam (1968), Turner \& Rippon (1973), Daniells et al. (1987) e Salomão (1995) que também encontraram menores períodos entre a emergência da inflorescência e a colheita, em cachos ensacados.

No inverno a inferioridade do E-C para os cachos ensacados pode ser creditada à elevação de temperatura durante o estádio final de crescimento e maturação fisiológica dos frutos, que ocorreu entre os meses de setembro e outubro/96 (Figura 2). Perumal \& Adam (1968) verificaram efeito do ensacamento sobre $\mathrm{E}-\mathrm{C}$ mais pronunciado no inverno e salientaram que a colheita foi efetuada nessa estação, em condições de frio e chuvas. O referido comportamento é atribuído pelos autores como conseqüência da elevação da temperatura no interior dos sacos, ocorrendo na vizinhança das pencas superiores uma diferença de $1,7^{\circ} \mathrm{C}$ entre frutos ensacados e não ensacados. $O$ ar mais quente concentrado na parte superior dos sacos foi o principal fator acelerante do crescimento das pencas superiores.

No verão, todo o ciclo de desenvolvimento do cacho aconteceu nos meses mais quentes do ano, portanto, como era esperado, o E-C foi menor nos cachos ensacados. Johns \& Scott (1989) comprovaram mediante comparação de vários tipos de sacos usados para proteção de cachos que ocorreu aumento de temperatura dentro dos mesmos, sendo mais elevadas no verão. Há um consenso de que o aumento da temperatura, em torno de $1^{\circ} \mathrm{C}$, que ocorre em função do ensacamento, reduz o intervalo E-C (Perumal \& Adam, 1968; Ganry, 1975; Robinson \& Nel, 1984; Johns \& Scott, 1989 e Salomão,1995).

O intervalo E-C observado no outono não diferiu entre os tratamentos (cachos ensacados e não ensacados). É interessante ressaltar 
que as bananeiras submetidas aos tratamentos no outono, tiveram as melhores condições climáticas para o desenvolvimento e produção, podendose inferir que o efeito do ensacamento depende tanto da época de realização, quanto das condições climáticas do período. Resultados semelhantes aos obtidos no outono foram verificados por Robinson \& Nel (1984) e Galán Saúco et al. (1996)

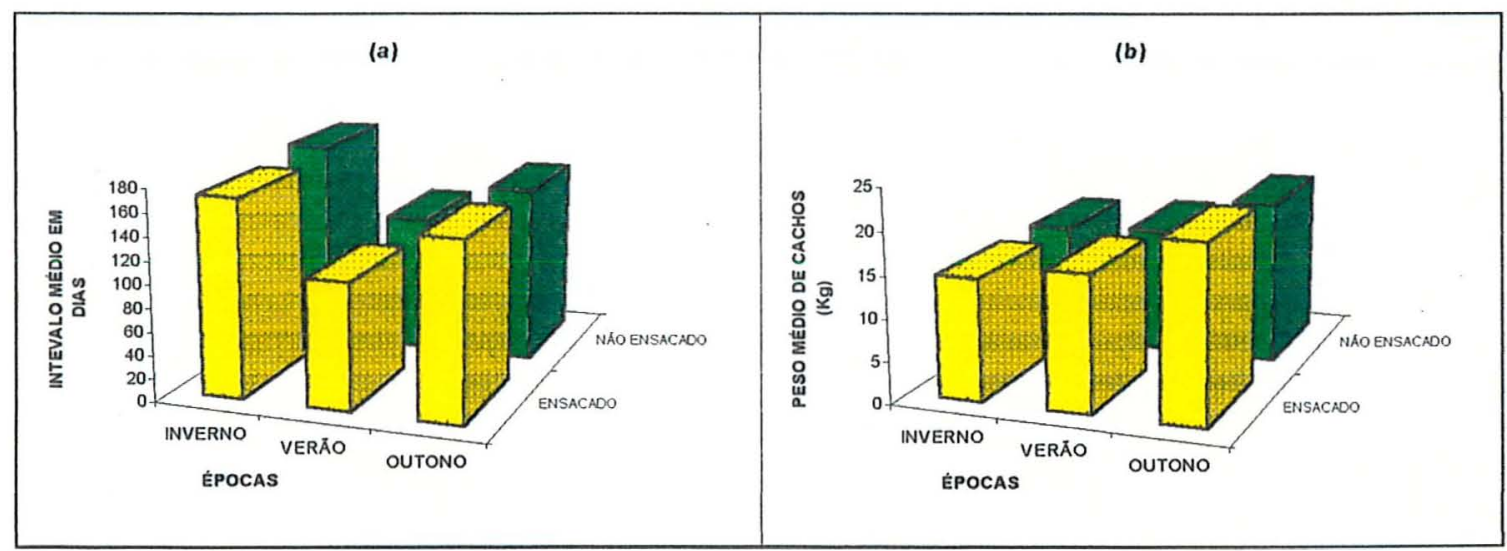

Figura 1 - a) Intervalo médio em dias entre emergência da inflorescência e a colheita e b) peso de cacho (em $\mathrm{kg}$ ) em função dos fatores ensacamento e épocas. Tietê - SP, 1997.

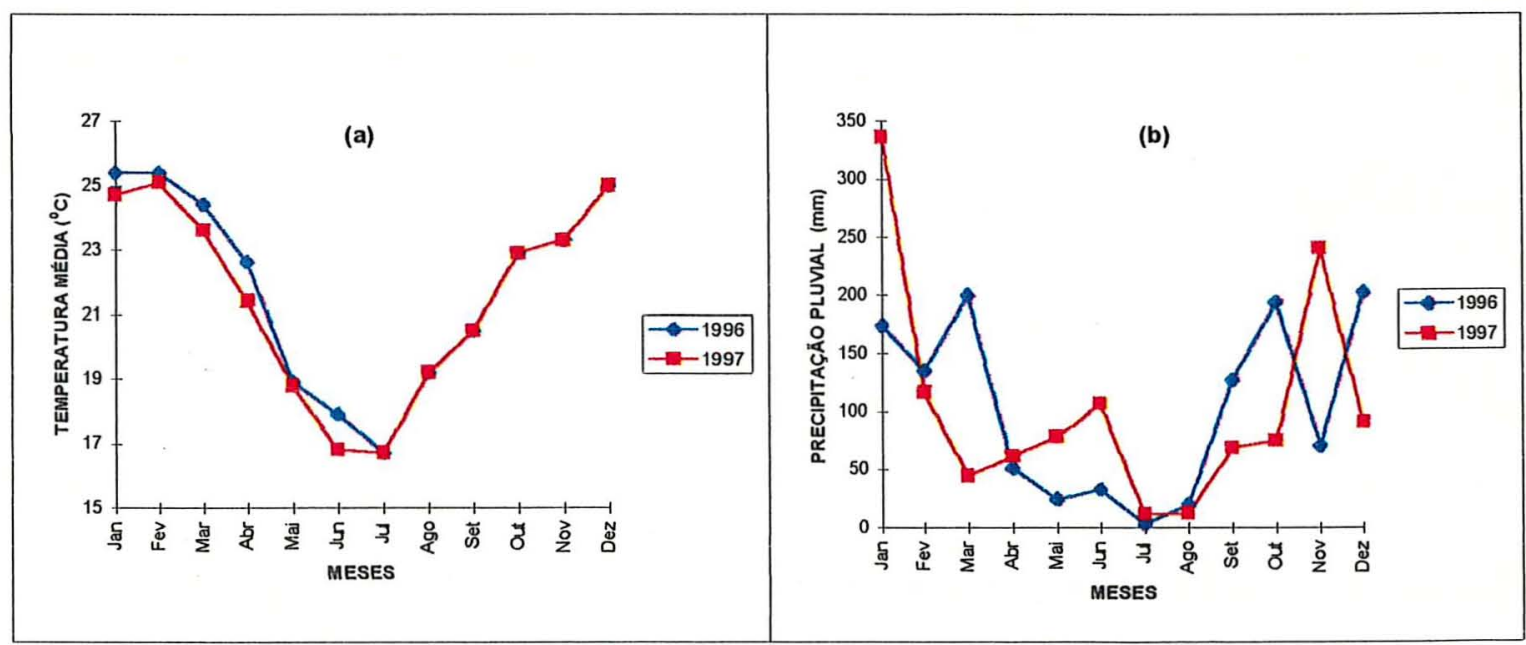

Figura 2 - a) Temperatura média mensal $\left({ }^{\circ} \mathrm{C}\right)$ e b) precipitação pluvial (mm) nos anos de 1996 e 1997, em Tietê - SP. Fonte: Estação Experimental de Tietê - IAC. 


\subsubsection{Peso do cacho}

Mediante os resultados obtidos e apresentados na Tabela 2 , verifica-se que houve significância apenas para o fator épocas. Conforme o teste de Tukey, a maior média de peso observada foi no outono, significativamente diferente das médias obtidas no inverno e no verão, que não diferiram entre si. A Figura 1 ilustra estes resultados.

As diferenças de peso de cacho verificadas nas diferentes épocas podem ser explicadas pelas condições climáticas que ocorreram durante o desenvolvimento das plantas, formação e frutificação dos cachos. Temperatura e precipitação são fatores de relevante importância no cultivo da bananeira. Altas produções são obtidas em condições de temperatura elevada e uniforme, bem como permanente disponibilidade de umidade no solo (Alves et al., 1996). Conforme Medina (1985), a temperatura ótima para o desenvolvimento da bananeira situa-se em torno de $26^{\circ} \mathrm{C}$.

A produção do período de inverno sofreu conseqüencias de estiagem e baixas temperaturas. O verão foi precedido por período de poucas chuvas e baixas temperaturas (abril a agosto/96), o qual coincidiu com a fase de desenvolvimento vegetativo e possivelmente com o início da diferenciação floral. Segundo Medina (1985), a quantidade de chuva exigida pela bananeira varia de 3 a $8 \mathrm{~mm}$ por dia. Portanto, no referido periodo, a precipitação mensal (Figura 2) foi inferior ao limite mínimo necessário requerido pela cultura. A mudança da fase de desenvolvimento vegetativo do meristema apical para o estádio floral, ocorre três a quatro meses antes da emergência da inflorescência no ápice da planta (Turner, 1972a,b e Holder \& Gumbs, 1982), podendo chegar a mais de seis meses (Soto Balestero \& Ruiz, 1992). Portanto, a diferenciação floral deve ter acontecido em condição desfavorável, refletindo posteriormente sobre o desenvolvimento do cacho. Os dados meteorológicos da região dão suporte a esta explicação (Figura 2). As maiores produções obtidas no outono, devem-se com certeza as melhores condições climáticas 
que ocorreram, desde a diferenciação floral nas bananeiras (novembro e dezembro/96) até o periodo de frutificação.

Tabela 2 - Médias da variável peso de cacho $(\mathrm{kg})$ em função dos fatores ensacamento e épocas em banana 'Nanicão'. Tietê - SP, 1997.

\begin{tabular}{|c|c|c|c|c|}
\hline \multirow[b]{2}{*}{ TRATAMENTOS } & \multicolumn{3}{|c|}{ ÉPOCAS } & \multirow[b]{2}{*}{ MÉDIAS } \\
\hline & INVERNO & VERÃO & OUTONO & \\
\hline & \multicolumn{3}{|c|}{ Peso de cacho $(\mathrm{kg})$} & \\
\hline ENSACADO & 14,45 & 16,20 & 20,91 & $17,19 a$ \\
\hline NÄO ENSACADO & 14,42 & 15,03 & 19,42 & $16,29 a$ \\
\hline MÉDIAS & $14,44 \mathrm{~B}$ & $15,61 \mathrm{~B}$ & $20,17 \mathrm{~A}$ & \\
\hline
\end{tabular}

$\mathrm{CV}(\%)=17,1 \quad \operatorname{DMS}(5 \%)^{*}: 1=4,31 ; 2=3,71 ; 3=2,49$

Médias seguidas de mesmas letras minúsculas nas colunas e maiúsculas nas linhas, não diferem entre si pelo teste de Tukey em nivel de $5 \%$.

*1-médias de ensacamento dentro das épocas; 2-médias de época; 3-médias de ensacamento.

Não foram verificadas diferenças em relação a peso dos cachos ensacados e não ensacados. Os resultados obtidos corroboram aqueles verificados por Sampaio \& Simão (1970), Daniells et al. (1992) e Salomão (1995) em pesquisas com as cultivares 'Nanica', 'Williams' e 'Mysore', respectivamente, os quais não encontraram diferenças entre tratamentos com cachos ensacados ou não. São discordantes, entretanto, com Cann (1965), Robinson \& Nel (1984), e Galán Saúco et al. (1996), que registraram aumentos significativos de peso em relação a cachos ensacados da cultivar Dwarf Cavendish.

\subsubsection{Comprimento, diâmetro e densidade de frutos}

Em referência a variáveis comprimento e diâmetro, são apresentados apenas os dados concernentes à $2^{a}$ penca superior, pois é 
considerada como representativa do cacho, para efeito de uniformização de amostras (Carvalho et al., 1989 e Galán Saúco et al., 1996), e indicada para determinação do ponto de colheita com base no diâmetro do fruto (Soto Balestero et al. 1992).

O comprimento do fruto foi maior no verão e outono em relação ao verificado no inverno. Não houve diferença significativa entre os comprimentos dos frutos de cachos ensacados e não ensacados, semelhante ao que ocorreu para o peso dos cachos.

Quanto ao diâmetro de frutos da $2^{\mathrm{a}}$ penca superior, não foram observadas diferenças entre as médias de ensacamento, de época e da interação ensacamento x época (Tabela 3).

Para a variável densidade, não foram detectadas diferenças significativas entre nenhuma das épocas ou ensacamento (Tabela 3). Embora as médias não tenham diferido estatisticamente, a densidade dos frutos de cachos ensacados tendem a ser inferiores a 1,0, acontecendo o contrário para não ensacados que superou o valor correspondente à densidade da água. Este aspecto é importante do ponto de vista prático, pois as pencas ou buquês de frutos apresentando densidades abaixo do referido limite não afundarão nos tanques de lavagem e tratamento químico, facilitando o trabalho no galpão de embalagem. Lichtemberg (1996) ressalta que a redução da densidade é um dos benefícios indiretos da protecão de cachos com polietileno em climas subtropicais.

Singh et al. (1987), em estudo sobre crescimento e maturidade, encontrou valores variando de 0,970 a 0,993 em banana 'Basrai', em sistema tradicional de condução de cachos. Salomão (1995) evidencia, em seus resultados, densidades superiores a 1,00 para 'Mysore', cujos cachos foram cobertos com envoltório plástico, e valores inferiores para frutos de cachos não ensacados. 
As variações de densidade estão relacionadas a cultivares, nivel de nutrição potássica, ponto de colheita (Lassoudière, 1978) e, provavelmente, às condições climáticas. Salomão (1995) sugere que deve existir um mecanismo fisiológico, que atua sobre a expansão celular e o acúmulo de amido, o que faz preencher os espaços vazios das cavidades loculares.

Tabela 3 - Médias das variáveis comprimento $(\mathrm{cm})$, diâmetro $(\mathrm{mm})$ e densidade de frutos $\left(\mathrm{g} / \mathrm{cm}^{3}\right)$ da $2^{a}$ penca superior, em função dos fatores ensacamento e épocas em banana 'Nanicão'. Tietê - SP, 1997

ÉPOCAS

TRATAMENTOS INVERNO VERÃO OUTONO MÉDIAS

\begin{tabular}{|c|c|c|c|c|}
\hline \multirow[b]{2}{*}{ ENSACADO } & \multicolumn{3}{|c|}{ Comprimento $(\mathrm{cm})$} & \multirow[b]{2}{*}{$21,02 a$} \\
\hline & 18,99 & 22,38 & 21,69 & \\
\hline NÃO ENSACADO & 18,96 & 21,94 & 20,94 & $20,61 a$ \\
\hline MÉDIAS & $18,97 \mathrm{~B}$ & $22,16 \mathrm{~A}$ & $21,31 \mathrm{~A}$ & \\
\hline \multirow[t]{2}{*}{$\mathrm{CV}(\%)=20,8$} & \multicolumn{4}{|c|}{$\operatorname{DMS}(5 \%)^{*}: \quad 1=2,13 ; 2=1,83 ; \quad 3=1,23$} \\
\hline & \multicolumn{3}{|c|}{ Diâmetro $(\mathrm{mm})$} & \\
\hline ENSACADO & 35,00 & 37,31 & 36,61 & $36,42 a$ \\
\hline NÃO ENSACADO & 34,25 & 35,91 & 36,53 & $35,43 a$ \\
\hline MÉDIAS & $34,63 \mathrm{~A}$ & $36,61 \mathrm{~A}$ & $36,53 \mathrm{~A}$ & \\
\hline \multirow[t]{2}{*}{$\mathrm{CV}(\%)=5,43$} & \multicolumn{4}{|c|}{$\operatorname{DMS}(5 \%)^{*}: 1=2,93 ; 2=2,53 ; 3=1,69$} \\
\hline & \multicolumn{3}{|c|}{ Densidade $\left(\mathrm{g} / \mathrm{cm}^{3}\right)$} & \\
\hline ENSACADO & 1,002 & 0,999 & 0,998 & $0,999 a$ \\
\hline NÃO ENSACADO & 1,006 & 1,001 & 0,995 & $1,001 \mathrm{a}$ \\
\hline MÉDIAS & $1,004 \mathrm{~A}$ & $1,000 \mathrm{~A}$ & $0,996 \mathrm{~A}$ & \\
\hline
\end{tabular}

Médias seguidas de mesmas letras minúsculas nas colunas e maiúsculas nas linhas, não diferem entre si pelo teste de Tukey em nivel de $5 \%$.

*1-médias de ensacamento dentro das épocas; 2-médias de época; 3-médias de ensacamento 


\subsubsection{Firmeza da polpa}

Embora não tenha havido interação significativa entre ensacamento $x$ época, o teste de Tukey detectou que a firmeza média dos frutos verdes $\left(\mathrm{kgf} / \mathrm{cm}^{2}\right)$ de cachos ensacados foi significativamente inferior aos ensacados no inverno (Tabela 4). Os resultados confirmam aqueles relatados por Salomão (1995), cujos frutos procedentes de cachos ensacados apresentaram firmeza menores nos estádios iniciais da maturação.

Verifica-se também pelo teste de Tukey que no outono a média de firmeza foi superior à do verão. No inverno, foi intermediária, não diferiu significativamente da média do verão nem do outono.

Tabela 4 - Médias da variável firmeza de polpa de frutos verdes $\left(\mathrm{kgf} / \mathrm{cm}^{2}\right)$, em função dos fatores ensacamento e épocas em banana 'Nanicão'. Tietê - SP, 1997.

ÉPOCAS

TRATAMENTOS INVERNO VERÃO OUTONO MÉDIAS

\begin{tabular}{|c|c|c|c|c|}
\hline \multirow[b]{2}{*}{ ENSACADO } & \multicolumn{3}{|c|}{ Firmeza de polpa $\left(\mathrm{kgf} / \mathrm{cm}^{2}\right)$} & \multirow[b]{2}{*}{$17,97 \mathrm{~b}$} \\
\hline & 17,12 & 16,78 & 20,02 & \\
\hline NÃO ENSACADO & 20,93 & 19,58 & 21,93 & $20,81 a$ \\
\hline MÉDIAS & $19,02 \mathrm{AB}$ & $18,18 \mathrm{~B}$ & $20,98 \mathrm{~A}$ & \\
\hline $\operatorname{CV}(\%)=19,39$ & \multicolumn{4}{|c|}{ DMS $(5 \%)^{\star}: \quad 1=2,88 ; 2=2,48 ; 3=1,66$} \\
\hline
\end{tabular}

As variações na firmeza dos frutos podem ocorrer entre cultivares distintas, ou mesmo entre plantas de um mesmo pomar. Frutos de maior tamanho, cujas células são alongadas, apresentando paredes celulares finas e com maiores espaços entre as mesmas, são propensos a serem mais macios 
(Ryugo, 1988). Este parece ser o argumento para explicar a variação ocorrida entre firmeza de frutos verdes de cachos ensacados e não ensacados, pois estes geralmente são maiores, embora no caso do presente trabalho, a variável peso de cacho (correlacionada com comprimento de fruto), não diferiu estatisticamente, apesar de maior em todas as épocas.

As variações de firmeza entre as épocas outono e verão provavelmente estão relacionadas ao teor de água na polpa, como sugerem também os resultados referentes à relação polpa/casca (Tabela 5) que apresentam diferenças semelhantes em termos das referidas épocas

\subsubsection{Relação polpa/casca}

Observa-se na Tabela 5 que para a relação polpa/casca de frutos verdes só foi detectada diferença significativa entre médias de épocas. A maior média foi no inverno, significativamente maior que a do verão; a média do outono ficou como intermediária, não diferindo da maior (inverno) nem da menor (verão)

As relações encontradas estão de acordo com aquelas verificadas por Barnell (1941), cujas variações foram de 1,2 a 1,6 em bananas verdes. Relação polpa/casca variando de 1,36 a 1,86, conforme a ascensão do amadurecimento, é reportada por Chacón et al. (1987) em banana Musa cavendishii. Os resultados obtidos também são concordantes com aqueles verificados por Salomão (1995), em banana 'Mysore', por não apresentar diferença entre os frutos de cachos ensacados e controle.

No inverno, a relação polpa/casca foi maior que nas outras épocas, embora não significativa em comparação ao outono. Esse fato deve ter acontecido em função dos frutos terem sofrido a ação de um período frio e seco, retendo maior quantidade de água em comparação a frutos desenvolvidos numa condição mais favorável, em conseqüência de uma maior passagem de água do engaço para a polpa, a uma redução na transpiração ou 
à ocorrência de ambos os fatores, conforme explana Bleinroth (1985) a respeito de ocorrência dessa natureza.

O aumento da relação polpa/casca é função da acumulação de água na polpa, produto da degradação de carboidratos e da transferência osmótica de água da casca a polpa (Palmer, 1971).

Tabela 5 - Médias da variável relação polpa/casca de frutos verdes, em função dos fatores ensacamento e épocas em banana 'Nanicão'. Tietê - SP, 1997.

\begin{tabular}{|c|c|c|c|c|}
\hline \multirow[b]{2}{*}{ TRATAMENTOS } & \multicolumn{3}{|c|}{ ÉPOCAS } & \multirow[b]{2}{*}{ MÉDIAS } \\
\hline & INVERNO & VERÃO & OUTONO & \\
\hline & \multicolumn{3}{|c|}{ Relação polpa/casca } & \\
\hline ENSACADO & 1,41 & 1,27 & 1,40 & $1,36 a$ \\
\hline NÃO ENSACADO & 1,44 & 1,33 & 1,34 & $1,37 a$ \\
\hline MÉDIAS & $1,43 \mathrm{~A}$ & $1,30 \mathrm{~B}$ & $1,37 \mathrm{AB}$ & \\
\hline
\end{tabular}

$\mathrm{CV}(\%)=6,92 \quad \operatorname{DMS}(5 \%)^{*}: 1=0,14 ; 2=0,12 ; 3=0,08$

Médias seguidas de mesmas letras minúsculas nas colunas e maiúsculas nas linhas, não diferem entre si pelo teste de Tukey, em nivel de $5 \%$.

*1-médias de ensacamento dentro das épocas; 2-médias de época; 3-médias de ensacamento

\section{$3.5 .6 \mathrm{pH}$ da polpa}

Não houve diferenças significativas para $\mathrm{pH}$ da polpa de frutos verdes em relação ao ensacamento, épocas e interação ensacamento x época (Tabela 6). As médias estão na faixa prevista por Bleinroth (1985), que considera aceitável a variação de 5,0 a 5,6 para frutos verdes.

A concentração de $\mathrm{H}^{+}$em frutos, tende a ser mais elevada à medida que diminui a temperatura. Este comportamento têm relação com as caracteristicas varietais dos frutos (Claypool \& Davis, 1959). Em pesquisa com pêssego, os autores verificaram uma tendência de diminuição na concentração 
de $\mathrm{H}^{+}$à medida que a temperatura de armazenamento aumentava de 0 a 5.6 ${ }^{\circ} \mathrm{C}$. Estes estudos inferem que as perdas de $\mathrm{H}^{+}$são em função da temperatura anteriormente ao processo de amadurecimento e que variações nas concentrações de $\mathrm{H}^{+}$podem ocorrer devido a eventuais condições climáticas predominantes na época de colheita.

No presente trabalho o efeito do aumento da temperatura nos cachos ensacados, principamente no verão, não chegou a interferir sobre o pH dos frutos verdes. Possivelmente a elevação da temperatura no interior dos sacos não tenha sido suficiente para causar variação no pH.

Tabela 6 - Médias da variável pH da polpa de frutos verdes, em função dos fatores ensacamento e épocas em banana 'Nanicão'. Tietê - SP, 1997.

\begin{tabular}{|c|c|c|c|c|}
\hline \multirow[b]{2}{*}{ TRATAMENTOS } & \multicolumn{3}{|c|}{ ÉPOCAS } & \multirow[b]{2}{*}{ MÉDIAS } \\
\hline & INVERNO & VERÃO & OUTONO & \\
\hline & \multicolumn{3}{|c|}{ pH da polpa } & \\
\hline ENSACADO & 5,59 & 5,56 & 5,56 & $5,57 a$ \\
\hline NÃO ENSACADO & 5,67 & 5,59 & 5,62 & $5,63 a$ \\
\hline MÉDIAS & $5,63 \mathrm{~A}$ & $5,58 \mathrm{~A}$ & $5,59 \mathrm{~A}$ & \\
\hline
\end{tabular}

Médias seguidas de mesmas letras minúsculas nas colunas e maiúsculas nas linhas, não diferem entre si pelo teste de Tukey, em nivel de $5 \%$.

*1-médias de ensacamento dentro das épocas; 2-médias de época; 3-médias de ensacamento

\subsubsection{Sólidos solúveis}

Conforme se percebe na Tabela 7, para sólidos solúveis dos frutos verdes houve diferença significativa apenas entre as médias do fator ensacamento. Os índices alcançados estão próximos dos limites a que 
chegaram Sgarbieri \& Figueiredo (1971), que foram 3,65 e $4,47 \mathrm{~g} / 100 \mathrm{~g}$ em frutos verdes.

Os sólidos solúveis encontram-se dissolvidos na polpa e apresentam a tendência de aumentar conforme a maturação (Chitarra \& Chitarra, 1990). De acordo com Bleinroth (1985), os sólidos solúveis aumentam com a maturação da fruta, devido à degradação do amido em açúcares solúveis. Analogamente, os teores expressos para a variável analisada estão em concordância com Salomão (1995), cujos niveis absolutos de amido em frutos de banana 'Mysore' desenvolvidos sob embalagem tenderam a ser maiores que os frutos do controle. O autor sugere que o maior teor de amido e, conseqüentemente, menor de sólidos solúveis em frutos ensacados seja resultante do maior tamanho destes em comparação aos não ensacados. No presente experimento verificou-se em todas as épocas médias maiores para peso de cacho e comprimento de frutos. Embora não tenham sido significativas, induzem a confirmar a tendência proposta pelo pesquisador citado.

Tabela 7 - Médias da variável sólidos solúveis ( $\left.{ }^{\circ} \mathrm{Brix}\right)$ de frutos verdes, em função dos fatores ensacamento e épocas em banana 'Nanicão'. Tietê - SP, 1997.

ÉPOCAS

\section{TRATAMENTOS INVERNO VERÃO OUTONO MÉDIAS}

\begin{tabular}{lcccc}
\hline & \multicolumn{3}{c}{ Sólidos solúveis ( $\left.{ }^{\circ} \mathrm{Brix}\right)$} & $3,62 \mathrm{~b}$ \\
\cline { 2 - 4 } ENSACADO & 3,70 & 3,46 & 3,70 & $4,75 \mathrm{a}$ \\
\hline NÄO ENSACADO & 4,58 & 4,15 & 5,51 & $4,60 \mathrm{~A}$ \\
\hline MÉDIAS & $4,14 \mathrm{~A}$ & $3,80 \mathrm{~A}$ & 4,$08 ; 3=0,72$ \\
\hline CV $(\%)=19,82$ & DMS $(5 \%)^{*}:$ & $1=1,25 ; 2=1,08 ;$ \\
$\begin{array}{l}\text { Médias seguidas de mesmas letras minúsculas nas colunas e maiúsculas nas linhas, não } \\
\text { diferem entre si pelo teste de Tukey em nivel de 5\%. }\end{array}$ \\
*1-médias de ensacamento dentro das épocas; 2-médias de época; 3-médias de ensacamento
\end{tabular}




\subsection{CONCLUSÕES}

Nas condições em que foi realizada a pesquisa, os resultados comparativos entre cachos de banana 'Nanicão' ensacados e não ensacados em diferentes épocas, inferem o seguinte:

- O ensacamento realizado no verão e inverno propicia um menor intervalo em dias entre a emergência da inflorescência e a colheita;

- O ensacamento não proporciona aumento no peso de cacho;

- A densidade frutos de banana de cachos ensacados no verão e outono é menor que 1,00;

- O teor de sólidos solúveis e firmeza é menor em frutos verdes de cachos ensacados;

- O ensacamento não interfe sobre $\mathrm{opH}$ e relação polpa/casca de frutos verdes. 
PROTEÇÃO DE CACHOS DE BANANEIRA ‘GRANDE NAINE’ (MUSa sp. AAA), COM SACOS DE POLIETILENO, EM DIFERENTES PERIODOS APÓS A EMERGÊNCIA DA INFLORESCÊNCIA

\subsection{RESUMO}

Conduziu-se o experimento em bananal estabelecido na Fazenda Diamante, Município de Tietê - SP, visando a avaliar o efeito do ensacamento de cachos de banana em três períodos após a emergência da inflorescência (10, 20 e 30 dias) sobre a cultivar Grande Naine. Utilizou-se o delineamento em blocos ao acaso, com cinco repetições. As variáveis analisadas foram: intervalo em dias entre emergência da inflorescência e o ponto de colheita para o mercado externo (calibre de $34 \mathrm{~mm}$ de diâmetro dos frutos da $2^{\mathrm{a}}$ penca superior) e mercado interno (calibre de $34 \mathrm{~mm}$ de diâmetro dos frutos da $2^{\text {a }}$ penca inferior); peso de cachos; comprimento, diâmetro e densidade de frutos; firmeza de polpa, relação polpa/casca, $\mathrm{pH}$ e sólidos solúveis de frutos verdes. O ensacamento, independentemente do período, resultou em menor intervalo em dias entre a emergência da inflorescência e o ponto de colheita para 0 mercado externo; o ensacamento realizado 10 dias após a emergência da inflorescência, propiciou aumento de comprimento e diâmetro dos frutos das pencas superiores e reduziu o teor de sólidos solúveis em frutos verdes. $O$ ensacamento não interferiu sobre o peso de cacho, densidade, firmeza, relação polpa/casca e pH dos frutos verdes. 


\subsection{SUMMARY: PROTECTION OF BUNCHES OF BANANA 'GRANDE NAINE' (MUSa sp. AAA), WITH POLYETHYLENE BAGS, IN DIFFERENT PERIODS AFTER INFLORESCENCE}

An experiment was carried out in the banana plantation established in Fazenda Diamante, in the county of Tietê - SP, seeking to evaluate the effect of the bagging of banana bunches at three different times after inflorescence $(10,20$ and 30 days) of the variety Grande Naine. The experimental design used randomized blocks with five replications. The analyzed variables were: weight of bunches; interval in days between inflorescence and harvest for the external market (caliber of $34 \mathrm{~mm}$ of diameter of the fruits of the 2 nd superior hand) and internal market (caliber of $34 \mathrm{~mm}$ of diameter of the fruits of the 2nd inferior hand); length, diameter, density pulp firmness, pulp-to-peel ratio, $\mathrm{pH}$ and soluble solids of green fruits. The bagging, independently of when it took place, resulted in a smaller interval between inflorescence and the harvest point for the external market. The bagging done 10 days after inflorescence increased the length and diameter of the fruits of the 2 a superior hand reduced the soluble solids in green fruits. The bagging did not effect the bunch weight and density of green fruit, the firmness of the pulp, pulp-to-peel ratio and $\mathrm{pH}$ of the green fruits.

\subsection{INTRODUÇÃO}

A bananicultura no Brasil é caracterizada pela alta produção, suficiente para atender a demanda interna, e por ser inexpressiva no âmbito da comercialização internacional. Um dos problemas que contribui para a pequena participação no mercado externo é concernente à qualidade dos frutos produzidos.

Associada às condições edafoclimáticas favoráveis, as práticas culturais constituem os fatores básicos para que a cultura da bananeira 
expresse seu potencial de produtividade, resultando em maior produção e em produto de melhor qualidade. Outro fator decisivo para qualidade da banana é o manejo adequado, que deve ser propiciado aos frutos durante a colheita, o transporte e a comercialização.

O ensacamento dos cachos com polietileno é uma prática cultural que pode contribuir para melhorar a qualidade da banana produzida no Brasil. As vantagens são devidas ao aumento do peso do cacho, redução do período entre a emergência da inflorescência e a colheita; melhoria no visual dos frutos, tornando-os mais atrativos para o consumidor; aumento do tamanho final do fruto; proteção contra o frio, ação abrasiva das folhas e ataque de insetos (Heenan, 1973; Moreira, 1987; Soto Ballestero et al., 1992 e Lichtemberg, 1996).

Pesquisadores têm verificado ao longo dos anos que 0 rendimento e a qualidade de cachos desenvolvidos no inverno são melhores com o ensacamento. As elevações de produtividade são atribuídas ao aumento de peso, à redução do intervalo entre a emergência da inflorescência e a colheita, ou ambos (Robinson,1995).

Entretanto, o efeito sobre a redução do período entre a emergência da inflorescência e a colheita e aumento na produção nem sempre estão em concordância com os resultados obtidos em diferentes pesquisas.

Quanto ao peso de cachos os maiores aumentos devido ao ensacamento ficaram situados na faixa de 16 a 25\% (Cann, 1965; Robinson \& Nel, 1984 e Galán Saúco et al., 1996). Já em ensaios conduzidos por Sampaio \& Simão (1970), Daniells et al. (1992) e Salomão (1995), não foram reveladas diferenças para o peso de cacho entre tratamentos com cachos ensacados ou não.

Em relação ao intervalo entre a emergência da inflorescência e a colheita, a maioria dos pesquisadores encontraram um intervalo mais curto para cachos ensacados, comparados com os cachos não ensacados (Berril, 
1956; Turner \& Rippon, 1973 e Daniells et al., 1987). Robinson \& Nel (1984) não encontraram diferenças, enquanto que Scott et al. (1971) verificaram um maior intervalo para os cachos ensacados.

Os desacordos relacionados ao periodo da emergência da inflorescência e a colheita, podem ser explicadas pelos diferentes critérios para definição do ponto de colheita, nem sempre considerados como um grau de calibração, mas como uma determinação subjetiva. Também pode ser conseqüência dos diferentes tratamentos, como a proteção de cachos com sacos de polietileno abertos ou fechados na extremidade distal (Galán Saúco et al.,1996). Experimentos conduzidos em diferentes condições de clima também podem apresentar resultados discordantes, haja vista que fatores como temperatura, precipitação, umidade e luminosidade podem afetar direta ou indiretamente os efeitos do ensacamento.

São poucas as informações concernentes às transformações bioquímicas de frutos de cachos submetidos ao ensacamento, em comparação com frutos de cachos sem proteção. Salomão (1995) constatou, em banana 'Mysore', que o ensacamento proporcionou aumento na relação polpa/casca, maior teor de amido e menor firmeza de polpa nos estádios iniciais da maturação.

Moreira (1987) ressalta que, há vários anos, a prática do ensacamento é executada rotineiramente em bananais cultivados pelas grandes empresas agricolas em países da América Central. $O$ fato já era mencionado na década de 60 por Perumal \& Adam (1968). Atualmente a técnica é adotada em todas as regiões produtoras de banana do mundo (Alves \& Oliveira, 1997)

No Brasil, o envolvimento de cachos de banana com sacos de polietileno ainda é uma prática pouco usual. Todavia, recentemente tem crescido a adoção da tecnologia por alguns produtores de São Paulo e Santa Catarina. 
As informações sobre o uso do ensacamento são limitadas para atender as diferentes situações que ocorrem no Brasil (variedades utilizadas e condições climáticas). O desenvolvimento de pesquisas que venham propiciar possiveis respostas para uma melhor e adequada utilização do ensacamento de cachos de banana são, portanto, necessárias.

O objetivo deste trabalho foi de avaliar o efeito do ensacamento do cacho em diferentes épocas após a emergência da inflorescência $(10,20$ e 30 dias), avaliando-se a influência da proteção dos cachos sobre a produção, intervalo entre a emergência da inflorescência e a colheita e algumas características físicas e químicas dos frutos.

\subsection{MATERIAL E MÉTODOS}

\subsubsection{Local do experimento}

O experimento foi relizado, em bananal de propriedade do $\mathrm{Sr}$. João José Pascoal, localizado na Fazenda Diamante, Município de Tietê - SP (23 $07^{\prime}$ latitude sul e $47^{\circ} 43^{\prime}$ longitude oeste). O ensaio foi constituído pela cultivar Grande Naine. O bananal estava, na ocasião da instalação do experimento, com dois anos de idade e foi estabelecido no espaçamento de $2,10 \times 2,40 \mathrm{~m}$.

\subsubsection{Tratamentos}

$E 1$ = ensacamento dos cachos aos 10 dias após a emergência da inflorescência.

$E 2$ = ensacamento dos cachos aos 20 dias após a emergência da inflorescência.

E3 = ensacamento dos cachos aos 30 dias após a emergência da inflorescência.

Controle $=$ cachos não ensacados . 
As datas de aplicação dos tratamentos foram: E1 -11/03/97; E2 21/03/97 e E2 - 31/03/97.

Estas épocas foram estabelecidas tendo como base as recomendações que existem sobre a ocasião para se fazer o ensacamento (Soto Ballestero et al., 1992 e Lichtemberg, 1996). Na época E1 o cacho apresentava 3 a 4 pencas distais ainda cobertas pelas brácteas; na época E2, a última penca verdadeira apresentava os frutos iniciando a volta para cima e na época E3 a última penca verdadeira apresentava todos os frutos totalmente voltados para cima.

Anteriormente à instalação do ensaio foi efetuado um estudo de homogeneidade das plantas, objetivando selecioná-las quanto ao número de pencas e tamanho do cacho. Determinou-se, como padrão, a seleção de bananeiras de cachos com nove pencas. $O$ número estabelecido foi em função da ocorrência de maior percentual de plantas que apresentavam esta característica.

Conforme a casualização das parcelas, os cachos destacados para o ensacamento foram envolvidos com sacos plásticos de coloração azul, nas dimensões de $1,45 \mathrm{~m}$ de altura por $0,74 \mathrm{~m}$ de largura e $0,08 \mathrm{~mm}$ de espessura, com furos de $10,0 \mathrm{~mm}$ de diâmetro, distribuídos em quadrados a cada $85 \mathrm{~mm}$.

Anteriormente à colocação do saco procedeu-se à retirada do coração e a despistilagem nos frutos de ambos tratamentos. A extremidade distal do ráquis floral masculino foi quebrada a distância de 10 a $12 \mathrm{~cm}$ do ponto de inserção da última penca feminina e descartada, segundo recomendação de Moreira (1987). Os sacos foram fechados nas extremidades proximais dos cachos, conforme metodologia preconizada por Soto Ballestero et al. (1992). 


\subsubsection{Variáveis analisadas}

a) Intervalo em dias entre a emergência da inflorescência e o ponto de colheita (E-C). Foram procedidas duas avaliações, baseando-se na variação do ponto de colheita de banana, o qual é determinado pelo mercado a que se destina. Quando os frutos são destinados ao mercado externo devem ser colhidos quando a $2^{\mathrm{a}}$ penca superior apresenta frutos com $34 \mathrm{~mm}$ de diâmetro (padrão internacional). Para o mercado interno, as bananas podem ser colhidas em estádio mais avançado ( 36 a $38 \mathrm{~mm}$ ), conforme Bleinroth (1985) e Moreira (1987), que equivale ao diâmetro de $34 \mathrm{~mm}$ da $2^{\mathrm{a}}$ penca inferior no presente experimento. Portanto as variáveis referentes a E-C. foram:

a1) Intervalo em dias entre a emergência da inflorescência e o calibre de $34 \mathrm{~mm}$ de diâmetro dos frutos da $2^{\mathrm{a}}$ penca superior (E-C1), correspondente ao padrão internacional. Para essa determinação foram procedidas medições sistemáticas com o auxilio de calibrador, nos frutos centrais da fileira distal. Quando os frutos atingiam o diâmetro de $34 \mathrm{~mm}$. registrava-se a data para estabelecer o E-C1.

a2) Intervalo em dias entre a emergência da inflorescência e o calibre de $34 \mathrm{~mm}$ de diâmetro dos frutos da $2^{a}$ penca inferior (E-C2), correspondente ao padrão para o mercado interno, determinado conforme procedimento adotado para $2^{\mathrm{a}}$ penca superior.

A colheita foi realizada após essa avaliação (EC-2), seguindo-se a execução das avaliações subseqüentes.

b) Peso médio do cacho $(\mathrm{kg})$ - pesagem do cacho efetuada em balança marca Filizola com capacidade de $150 \mathrm{~kg}$.

c) Comprimento médio dos frutos $(\mathrm{cm})$ da $2^{\mathrm{a}}$ penca superior (CFPS) - medições feitas com trena metálica flexível, na face côncava das bananas. 
d) Comprimento médio dos frutos $(\mathrm{cm})$ da $2^{\mathrm{a}}$ penca inferior (CFPI) - metodologia de medição igual a do item " $\mathrm{c}$ ".

e) Diâmetro médio dos frutos $(\mathrm{mm})$ da $2^{\mathrm{a}}$ penca superior (DFPS) medições feitas com paquímetro na região central dos frutos, perpendicularmente ao maior eixo.

f) Diâmetro médio dos frutos $(\mathrm{cm})$ da $2^{\mathrm{a}}$ penca inferior (DFPI) metodologia de medição igual à do item " $e$ ".

g) Densidade de frutos $\left(\mathrm{g} / \mathrm{cm}^{3}\right)$ - foram pesados três buquês com seis frutos verdes por repetição, os quais foram imersos em recipiente contendo água, para determinação do volume dos frutos mediante o deslocamento da água. A densidade foi estabelecida pelo quociente massa/volume.

h) Firmeza de frutos verdes - medida pela resistência ao penetrômetro FT 327, no terço distal do fruto.

i) Relação polpa/casca de frutos verdes - obtida mediante pesagem de polpa e casca dos frutos amostrados para esse fim, em balança semi-analítica.

j) $\mathrm{pH}$ de frutos verdes - medido através de peagâmetro marca DIGIMED, modelo DMPH-2, usando-se uma amostra de cada repetição, segundo metodologia preconizada pelo INSTITUTO ADOLFO LUTZ (1985).

1) Teor de sólidos solúveis de frutos verdes e maduros determinado segundo metodologia recomendada por Harman \& Watkins (1981). Uma porção de polpa de cada amostra foi colocada sobre o prisma de um refratômetro de mesa marca ABBÉ e a leitura feita em ${ }^{\circ}$ Brix, com correção da temperatura para $20^{\circ} \mathrm{C}$.

\subsubsection{Preparo dos frutos para análise}

Para avaliação das variáveis, os frutos foram amostrados da segunda à quarta pencas proximais de cada cacho (Salomão, 1995). Os 
cachos foram colhidos quando os frutos da fileira distal da segunda penca inferior atingiram o diâmetro de $34 \pm 1 \mathrm{~mm}$, medidos em suas regiōes equatoriais. O ponto de colheita guardou relação com a prática adotada para o comércio interno, em razão dos frutos apresentarem equivalência nas condições do experimento.

Os cachos foram colhidos, pesados e despencados pela manhä. As pencas selecionadas foram transportadas de imediato para as avaliações referentes ao comprimento, diâmetro e densidade de frutos, as quais foram executadas em Laboratório do Departamento de Horticultura da Escola Superior de Agricultura "Luiz de Queiroz" (ESALQ), em Piracicaba, São Paulo.

Para as avaliações de firmeza, relação polpa/casca, pH e sólidos solúveis foram utilizados seis frutos verdes de cachos correspondentes às parcelas do experimento. As determinações foram efetuadas em laboratório do Centro de Energia Nuclear na Agricultura (CENA), em Piracicaba, São Paulo.

\subsubsection{Delineamento experimental}

Empregou-se o delineamento em blocos ao acaso, com quatro tratamentos e cinco repetições. Cada parcela foi composta por três plantas. $O$ fator estudado foi ensacamento de cachos, em quatro niveis: 10 (E1); 20 (E2) e 30 dias (E3) após a emergência da inflorescência e o controle (cachos não ensacados).

\subsubsection{Análise Estatística}

Os dados obtidos a partir das avaliações foram submetidos a análise de variância, através do Sistema SANEST, aplicando-se o teste $\mathrm{F} \mathrm{e}$ procedendo-se o detalhamento da análise pelo teste de Tukey. 


\subsection{RESULTADOS E DISCUSSÃO}

\subsubsection{Intervalo em dias entre a emergência da inflorescência e a colheita}

O ponto de colheita de banana varia de acordo com o mercado a que se destina. Portanto, se os frutos são destinados ao mercado externo devem ser colhidos quando a $2^{\mathrm{a}}$ penca superior apresenta frutos com $34 \mathrm{~mm}$ de diâmetro (padrão internacional). Para o mercado interno, devido à maior proximidade e menor tempo gasto no transporte, as bananas podem ser colhidas em estádio mais avançado (36 a $38 \mathrm{~mm}$ ), de acordo com Bleinroth (1985) e Moreira (1987). Por esta razão, optou-se no presente trabalho em se proceder à colheita quando os frutos da $2^{\mathrm{a}}$ penca inferior atingiram o diâmetro de $34 \mathrm{~mm}( \pm 1)$, devido a assemelhar-se com o ponto de colheita adotado para o comércio interno. Usando essa metodologia também se obtiveram respostas para o caso de se realizar a colheita com base no padrão internacional, devido à análise do intervalo de dias entre a emergência da inflorescência e o calibre de $34 \mathrm{~mm}$ de diâmetro em frutos da $2^{\mathrm{a}}$ penca superior. Portanto, as inferências para a $2^{\mathrm{a}}$ penca superior devem ser relacionadas com o ponto de colheita embasado no padrão internacional, e a $2^{a}$ penca inferior com o ponto de colheita para o mercado interno.

De conformidade com a Tabela 1, os tratamentos E1, E2 e E3 não apresentaram diferenças significativas entre si, entretanto foram superiores ao controle, ou seja, independentemente da época, o ensacamento reduziu o intervalo em dias entre a emergência da inflorescência e o ponto de colheita para o mercado externo ( $E-C 1)$. Assim sendo, os frutos ensacados aos 10, 20 e 30 dias alcançaram o diâmetro de $34 \mathrm{~mm}$, aos 15, 13 e 12 dias. respectivamente, antes dos frutos não ensacados.

O ensacamento, realizado aos 10 dias após a emergência da inflorescência, exigiu a necessidade da retirada de algumas brácteas remanescentes que se soltaram ao abrir das pencas, posteriormente ao 
ensacamento. Na prática, essa operação é uma desvantagem do ensacamento precoce, devido à necessidade de aumentar a mão-de-obra.

Galán Saúco et al. (1996) ensacaram cachos aos 45 dias após a emergência e verificaram intervalos de 6 e 28 dias menores que o controle, em condições de altitudes de 200 e 320 m, respectivamente. A altitude da região onde conduziu-se o experimento é de $538 \mathrm{~m}$, portanto superior àquela em que o autor citado obteve a maior diferença em termos de redução de número de dias.

Tabela 1 - Médias dos intervalos (em dias) entre a emergência da inflorescência e a colheita, com base no ponto de colheita para exportação (E-C1) e para o mercado interno (E-C2), em função do fator período de ensacamento em banana 'Grande Naine'. Tietê - SP, 1997.

\begin{tabular}{lcc}
\hline Ensacamento & E-C1 (dias) & E-C2 (dias) \\
\hline E1 & $114 \mathrm{~b}$ & $131 \mathrm{a}$ \\
E2 & $116 \mathrm{~b}$ & $136 \mathrm{a}$ \\
E3 & $117 \mathrm{~b}$ & $137 \mathrm{a}$ \\
Controle (não ensacado) & $129 \mathrm{a}$ & $140 \mathrm{a}$ \\
\hline CV $(\%)$ & 4,70 & 6,21 \\
DMS $(5 \%)$ & 10,49 & 16,12 \\
\hline
\end{tabular}

Médias seguidas da mesma letra nas colunas não diferem entre si, pelo teste de Tukey em nivel de $5 \%$.

E1 - Ensacamento aos 10 dias após a emergência da inflorescência.

E2 - Ensacamento aos 20 dias após a emergência da inflorescência.

E3 - Ensacamento aos 30 dias após a emergência da inflorescência

$\mathrm{Na}$ Tabela 1, observa-se também que o intervalo em dias entre a emergência da inflorescência e o ponto de colheita para o mercado interno (EC2) não diferiu entre os tratamentos.

Fazendo-se a análise comparativa entre os pontos de colheita para o mercado externo $(E-C 1)$ e para o mercado interno $(E-C 2)$ dos cachos ensacados (tratamentos E1, E2 e E3, em comparação ao controle), observa-se 
que ocorreu antecipação de 17 a 20 dias favorável a E-C1, enquanto que para E-C2, a maior diferença foi de apenas 11 dias, constatada no tratamento E1 (cachos ensacados 10 dias após a emergência da inflorescência). A Figura 1 ilustra o comportamento ocorrido em relação aos intervalos E-C1 e E-C2.

De acordo com alguns autores (Perumal \& Adam, 1968; Salomão, 1995 e Galán Saúco et al., 1996) diferenças desta natureza são devidas ao crescimento diferenciado dos frutos entre as pencas, em razão da existência de um gradiente de temperatura no interior dos sacos, ao longo da extensão do cacho, expondo as pencas proximais a temperaturas mais altas. Este efeito é negativo, quando se pretende uniformizar os frutos, como por exemplo para adotar o padrão internacional, cujo diâmetro preconizado é de $34 \mathrm{~mm}$, pois no minimo as duas pencas distais terão que ser descartadas. Para o caso do mercado interno, já não existe este problema, haja vista que podem ser comercializadas com diâmetros que podem variar de 36 a $38 \mathrm{~mm}$.

O efeito do ensacamento sobre a redução do intervalo entre a emergência da inflorescência e a colheita apresenta divergências entre resultados de diferentes pesquisas, conforme anteriormente relatado. $\dot{E}$ provável que tais discordâncias ocorram em função dos diferentes critérios de determinação do ponto de colheita. Como se verifica neste trabalho, se a opção para o ponto de colheita fosse o calibre de $34 \mathrm{~mm}$ nos frutos da $2^{a}$ penca superior, haveria diminuição no período E-C. Caso se optasse pelo ponto de colheita visando ao mercado interno, não haveria diferença de intervalo $\mathrm{E}-\mathrm{C}$. 


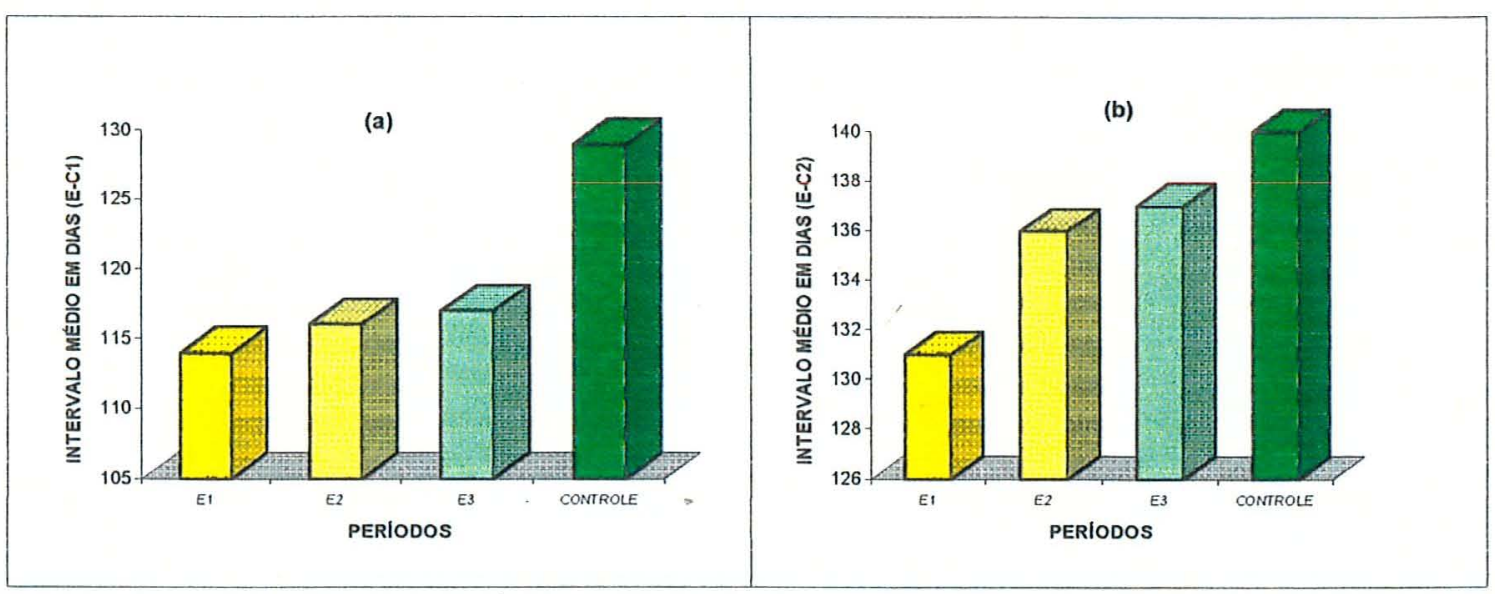

Figura 1 - a) Médias dos intervalos em dias entre a emergência da inflorescência e a colheita, com base no ponto de colheita para exportação $(E-C 1)$ e b) para o mercado interno (E-C2), em função do fator período de ensacamento após a emergência da inflorescência em banana 'Grande Naine'. Tietê - SP, 1997.

\subsubsection{Peso de cachos}

Conforme se observa na Tabela 2, os tratamentos não diferiram entre si. Embora não tenha ocorrido diferença estatística, foi relevante a diferença de peso verificada nos cachos ensacados aos 10 dias após a emergência da inflorescência, cujo aumento foi de $17,2 \%$, em relação ao controle. Este incremento de peso situa-se entre os valores obtidos em experimentos congêneres, relatados por Robinson \& Nell (1984) e Galán Saúco et al. (1996). O aumento de peso de cachos ensacados aos 20 e 30 dias foi de apenas 9,1 e 9,6\%, respectivamente. Estes resultados estão condizentes com aqueles reportados por Sampaio \& Simão (1970), Daniells et al. (1992) e Salomão (1995), que não encontraram diferenças para o peso de cachos ensacados ou não. 
Tabela 2 - Médias da variável peso de cacho $(\mathrm{kg})$, em função do fator periodo de ensacamento após a emergência da inflorescência em banana 'Grande Naine'. Tietê - SP, 1997.

\begin{tabular}{lc}
\hline Tratamento & PESO DE CACHO $(\mathrm{kg})$ \\
\hline E1 & $27,03 a$ \\
E2 & $25,16 a$ \\
E3 & $25,28 a$ \\
Controle (não ensacado) & $23,06 a$ \\
\hline CV $(\%)$ & 9,10 \\
DMS $(5 \%)$ & 4,30 \\
\hline
\end{tabular}

Médias seguidas da mesma letra nas colunas não diferem entre si, pelo teste de Tukey em nivel de $5 \%$.

E1 - Ensacamento aos 10 dias após a emergência da inflorescência.

E2 - Ensacamento aos 20 dias após a emergência da inflorescência.

E3 - Ensacamento aos 30 dias após a emergência da inflorescência

O aumento no peso dos cachos ensacados provavelmente é decorrente da maior temperatura no interior dos sacos, principalmente na parte superior, influenciando o maior crescimento dos frutos das pencas proximais (Perumal \& Adam, 1968; Salomão, 1995 e Galán Saúco, 1996). O maior comprimento de frutos da $2^{\mathrm{a}}$ penca superior de cachos ensacados aos 10 dias após a emergência da inflorescência (Tabela 3), comprova o referido efeito do ensacamento.

\subsubsection{Comprimento de frutos}

O comprimento de frutos da $2^{\mathrm{a}}$ penca superior (CFPS) dos cachos ensacados aos 10 dias após a emergência da inflorescência (E1) foi superior a dos frutos não ensacados, porém não diferiu em relação ao comprimento dos frutos ensacados aos 20 e 30 dias após a emergência da inflorescência (E2 e E3), enquanto estes não apresentaram diferença em comparação aos não ensacados (Tabela 3). 
Tabela 3 - Médias das variáveis comprimento $(\mathrm{cm})$ de frutos da $2^{a}$ penca superior (CFPS) e $2^{a}$ penca inferior (CFPI), em função do fator periodo de ensacamento após a emergência da inflorescência em banana 'Grande Naine'. Tietê - SP. 1997

\begin{tabular}{lcc}
\hline Tratamento & CFPS $(\mathrm{cm})$ & CFPI $(\mathrm{cm})$ \\
\hline E1 & $17,22 \mathrm{a}$ & $13,68 \mathrm{a}$ \\
E2 & $16,76 \mathrm{ab}$ & $13,49 \mathrm{a}$ \\
E3 & $16,44 \mathrm{ab}$ & $13,09 \mathrm{a}$ \\
Controle (não ensacado) & $15,74 \mathrm{~b}$ & $13,82 \mathrm{a}$ \\
\hline CV (\%) & 4,33 & 2,99 \\
DMS (5\%) & 1,34 & 0,76 \\
\hline Médias seguidas da mesma letra nas colunas não diferem entre si, pelo teste de Tukey em \\
nivel de 5\%. \\
E1 - Ensacamento aos 10 dias após a emergência da inflorescência. \\
E2 - Ensacamento aos 20 dias após a emergência da inflorescência. \\
E3 - Ensacamento aos 30 dias após a emergência da inflorescência.
\end{tabular}

Quanto ao comprimento dos frutos da $2^{a}$ penca inferior (CFPI) não foi verificada diferença significativa entre as médias dos tratamentos.

Comparando os resultados entre comprimento de frutos das pencas superiores $e$ inferiores, estes corroboram a explicação de que o crescimento diferenciado dos frutos entre as pencas ocorre em razão da existência de um gradiente de temperatura no interior dos sacos, conforme comentado anteriormente. Este fato ficou evidenciado no tratamento $E 1$, onde a média de peso de cacho foi maior (Tabela 2), ocorrendo o mesmo para o comprimento de frutos da $2^{a}$ penca superior. Já em relação à $2^{a}$ penca inferior não houve diferença significativa.

\subsubsection{Diâmetro de frutos}

De acordo com os resultados apresentados na Tabela 4 e ilustrados na Figura 2, o comportamento para variável diâmetro $(\mathrm{mm})$ de frutos da $2^{a}$ penca superior foi semelhante ao constatado para comprimento. $O$ mesmo aconteceu para o diâmetro de frutos da $2^{a}$ penca inferior, exceto no tratamento 
E3 (ensacamento aos 30 dias após a emergência da inflorescência), cujo diâmetro médio somente foi igual ao dos frutos não ensacados (controle).

Tabela 4 - Médias das variáveis diâmetro $(\mathrm{mm})$ de frutos da $2^{\mathrm{a}}$ penca superior (DFPS) e da $2^{a}$ penca inferior (DFPI), em função do fator período de ensacamento do cacho após a emergência da inflorescência em banana 'Grande Naine'. Tietê - SP, 1997.

\begin{tabular}{lcc}
\hline Tratamento & DFPS $(\mathrm{mm})$ & DFPI $(\mathrm{mm})$ \\
\hline E1 & $37,87^{\mathrm{a}}$ & $35,75 \mathrm{a}$ \\
E2 & $36,40 \mathrm{ab}$ & $34,14 \mathrm{ab}$ \\
E3 & $36,89 \mathrm{ab}$ & $33,42 \mathrm{~b}$ \\
Controle (não & $34,61 \mathrm{~b}$ & $34,62 \mathrm{ab}$ \\
ensacado) & & \\
\hline CV (\%) & 4,35 & 2,11 \\
DMS (5\%) & 2,97 & 1,37 \\
\hline
\end{tabular}

Médias seguidas da mesma letra nas colunas não diferem entre si, pelo teste de Tukey em nivel de $5 \%$.

E1 - Ensacamento aos 10 dias após a emergência da inflorescência.

E2 - Ensacamento aos 20 dias após a emergência da inflorescência.

E3 - Ensacamento aos 30 dias após a emergência da inflorescência

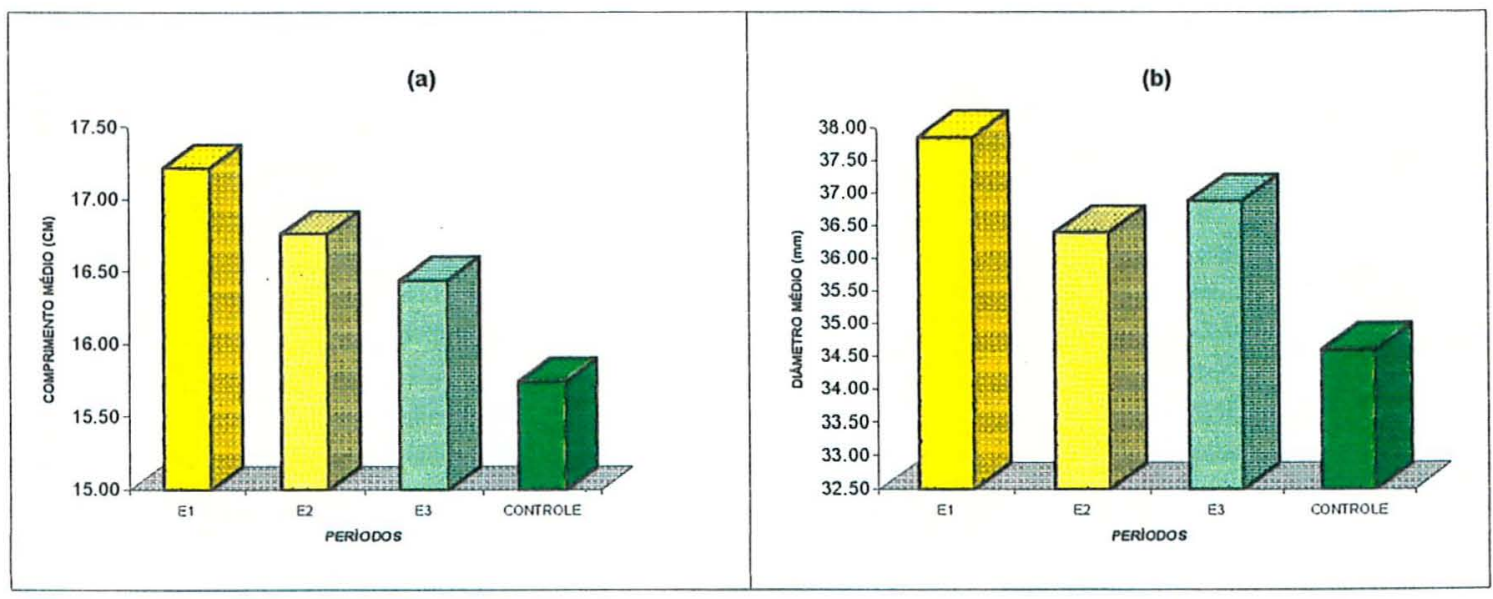

Figura2 - Médias de comprimento (a) e diâmetro (b) de frutos da $2^{\mathrm{a}}$ penca superior, em função do fator período de ensacamento após a emergência da inflorescência em banana 'Grande Naine'. Tietê SP, 1997. 
Com base nos resultados verificados. infere-se que o comprimento e diâmetro de frutos apresentam tendência de relacionar-se com o peso de peso de cacho ensacado. Em experimentos conduzidos por Galán Saúco et al. (1996), não ocorreu significância em relação ao diâmetro de frutos da $2^{a}$ penca inferior, porém foi constatado maior diâmetro para os frutos da $2^{a}$ penca superior.

\subsubsection{Densidade}

Observa-se na Tabela 5 que para a variável densidade não foram reveladas diferenças significativas entre nenhum dos tratamentos.

Os resultados corroboram aqueles encontrados por Singh et al. (1987), em estudo sobre crescimento e maturidade em banana 'Basrai', cujos valores variaram de 0,970 a 0,993, em sistema tradicional de condução de cachos. Soto Balestero et al. (1992) cita densidades de frutos variando de 0,89 a 0,94 e 0,86 a 0,93, nas cultivares Nanicão e Valery, respectivamente.

Salomão (1995) registrou densidades superiores a 1,00 para frutos de banana 'Mysore', cujos cachos foram ensacados, e valores inferiores para frutos de cachos não ensacados.

As variações de densidade estão relacionadas às cultivares, estado de nutrição potássica, ponto de colheita (Lassoudière, 1978) e provavelmente às condições climáticas. A existência de um mecanismo fisiológico atuando sobre a expansão celular e o acúmulo de amido, fazendo preencher os espaços vazios das cavidades loculares é a explicação proposta por Salomão (1995).

\subsubsection{Firmeza da polpa}

Para a variável firmeza de polpa dos frutos verdes, não foi destacada diferença significativa entre nenhum dos tratamentos (Tabela 5). 
Os resultados obtidos divergem daqueles mencionados por Salomão (1995), onde os frutos procedentes de cachos ensacados apresentaram firmeza menor nos períodos iniciais da maturação.

Variações na firmeza dos frutos podem ocorrer devido a diversos fatores, como cultivares distintas, ou até mesmo entre plantas de um mesmo pomar (Ryugo, 1988). O autor ressalta também que há uma tendência de frutos de maior tamanho serem mais macios, conforme o amadurecimento.

\subsubsection{Relação polpa/casca}

Verifica-se na Tabela 5 que os valores médios para a relação polpa/casca não diferiram entre os tratamentos. Embora não tenha ocorrido diferença significativa, observa-se uma tendência para os frutos de cachos ensacados apresentarem uma maior relação polpa/casca.

Os resultados obtidos estão de acordo com aqueles verificados por Salomão (1995), em banana 'Mysore', por não apresentar diferença entre frutos de cachos ensacados e controle. As proporções encontradas também são concordantes com aquelas relatadas por Barnell (1941), cujas variações podem situar-se entre 1,2 a 1,6 em bananas verdes. Desai \& Deshpande (1975), estudando as cultivares Giant Cavendish, Rajabale e Rasable, detectaram valores de 1,$34 ; 1,75$ e 2,27, em frutos verdes, respectivamente.

O aumento da relação polpa/casca é função da acumulação de água na polpa, produto da degradação de carboidratos e da transferência osmótica de água da casca para polpa (Palmer, 1971). De conformidade com os resultados obtidos e salientados pelos pesquisadores mencionados, evidencia-se que esse índice é variável entre cultivares, e o torna válido como coeficiente de amadurecimento, conforme propôs Loesecke (1950). 
Tabela 5 - Médias das variáveis densidade $\left(\mathrm{g} / \mathrm{cm}^{3}\right)$, firmeza de polpa $\left(\mathrm{kgf} / \mathrm{cm}^{2}\right)$ e relação polpa/casca dos frutos verdes, em função do fator periodo de ensacamento após a emergência da inflorescência em banana 'Grande Naine'. Tietê - SP, 1997.

\begin{tabular}{lccc}
\hline Tratamento & $\begin{array}{c}\text { Densidade } \\
\left(\mathrm{g} / \mathrm{cm}^{3}\right)\end{array}$ & $\begin{array}{c}\text { Firmeza } \\
\left(\mathrm{kgf} / \mathrm{cm}^{2}\right)\end{array}$ & $\begin{array}{c}\text { Relação } \\
\text { polpa/casca }\end{array}$ \\
\hline E1 & $0,999 a$ & $19,92 a$ & $1,48 a$ \\
E2 & $0,998 a$ & $21,68 a$ & $1,58 a$ \\
E3 & $0,994 a$ & $20,48 a$ & $1,55 a$ \\
Controle (não & $0,999 a$ & $20,28 a$ & $1,45 a$ \\
ensacado) & & & \\
\hline CV $(\%)$ & 0,93 & 11,31 & 6,84 \\
DMS $(5 \%)$ & 0,018 & 4,37 & 019 \\
\hline
\end{tabular}

Médias seguidas da mesma letra nas colunas não diferem entre si, pelo teste de Tukey em nivel de $5 \%$.

E1 - Ensacamento aos 10 dias após a emergência da inflorescência.

E2 - Ensacamento aos 20 dias após a emergência da inflorescência.

E3 - Ensacamento aos 30 dias após a emergência da inflorescência

\subsection{8 $\mathrm{pH}$ da polpa}

Verifica-se na Tabela 6 que não foram detectadas diferenças significativas entre médias dos tratamentos, para a variável $\mathrm{pH}$ dos frutos verdes. Os resultados estão em concordância com Simmonds (1973) e Palmer (1979), segundo esses autores os valores de $\mathrm{pH}$ em frutos verdes situam-se entre 5,0 a 5,8 .

A concentração de $\mathrm{H}^{+}$em frutos, tende a ser mais elevada quanto menor seja a temperatura. Este comportamento está relacionado às características varietais dos frutos (Claypool \& Davis, 1959). Os autores verificaram em pesquisa com pêssego uma tendência de diminuição na concentração de $\mathrm{H}^{+}$à medida que a temperatura de armazenamento aumentava de 0 a $5,6^{\circ} \mathrm{C}$. Estes estudos indicam que as perdas de $\mathrm{H}^{+}$são em função da temperatura anteriormente ao processo de amadurecimento e, variações nas concentrações de $\mathrm{H}^{+}$, podem ocorrer devido a eventuais condições climáticas predominantes na época de colheita. 
Neste trabalho o efeito do aumento da temperatura nos cachos ensacados, não chegou a interferir sobre o $\mathrm{pH}$ dos frutos verdes. Possivelmente a elevação da temperatura no interior dos sacos não tenha sido suficiente para causar variação no $\mathrm{pH}$.

\subsubsection{Sólidos solúveis}

Para a variável sólidos solúveis dos frutos verdes, foi detectada diferença significativa pelo teste de Tukey, em relação ao tratamento $E 1$ (ensacamento aos 10 dias após a emergência da inflorescência), cujo valor médio foi menor que dos outros tratamentos, inclusive do controle (Tabela 6).

O teor de sólidos solúveis dos frutos do tramento E1 (4,82 ${ }^{\circ}$ Brix) está dentro da faixa de variação reportada por Chacón et al. (1987), em estudo para determinação da escala fisíco-química de maturação de banana Musa cavendishii, cujo valor estabelecido foi de $4,69^{\circ} \mathrm{Brix}(S= \pm 0,58)$. Os teores dos demais tratamentos oscilaram entre 5,54 a 5,65 Brix, portanto um pouco acima da escala determinada pelos citados autores.

Simmonds (1973) relata que os açúcares solúveis estão presentes nos frutos verdes de banana em quantidades muito pequenas. ao redor de 1 a $2 \%$. Os teores de sólidos solúveis em frutos verdes apresentam variação maior do que a citada em difentes trabalhos publicados. Provavelmente essas diferenças estão relacionadas com a cultivar e condições climáticas, como também podem ser devidas ao estádio de maturidade fisiológica em que se encontram os frutos por ocasião da amostragem. Carvalho et al. (1982) registraram teores de sólidos solúveis em banana 'Prata' mensalmente ao longo de um ano e verificaram que o teor médio de um determinado mês diferiu de oito dos demais meses. 
Tabela 6 - Médias das variáveis pH da polpa e sólidos solúveis ( ${ }^{\circ}$ Brix) dos frutos verdes, em função do fator periodo de ensacamento após a emergência da inflorescência em banana 'Grande Naine'. Tietê - SP. 1997

\begin{tabular}{lcc}
\hline Tratamento & $\mathrm{pH}$ & Sólidos solúveis ( ${ }^{\circ}$ Brix) \\
\hline E1 & $5,52 \mathrm{a}$ & $4,82 \mathrm{~b}$ \\
E2 & $5,54 \mathrm{a}$ & $5,55 \mathrm{a}$ \\
E3 & $5,55 \mathrm{a}$ & $5,54 \mathrm{a}$ \\
Controle (não ensacado) & $5,65 \mathrm{a}$ & $5,65 \mathrm{a}$ \\
\hline CV (\%) & 1,41 & 3,71 \\
DMS (5\%) & 0,15 & 0,37 \\
\hline
\end{tabular}

Médias seguidas da mesma letra nas colunas não diferem entre si, pelo teste de Tukey em nivel de $5 \%$.

E1 - Ensacamento aos 10 dias após a emergência da inflorescência.

E2 - Ensacamento aos 20 dias após a emergência da inflorescência.

E3 - Ensacamento aos 30 dias após a emergência da inflorescência

Os sólidos solúveis aumentam com a maturação da fruta, devido à degradação do amido em açúcares solúveis (Bleinroth, 1985). Níveis absolutos de amido em frutos desenvolvidos em cachos ensacados tenderam a ser maiores que os frutos do controle, em estudo efetuado com banana 'Mysore' (Salomão, 1995). Por analogia, ocorreu o mesmo fenômeno no presente trabalho. A explicação do citado autor de que esse fato seja decorrente do maior peso inicial dos frutos provenientes de cachos ensacados, também se aplica ao que aconteceu no ensaio em questão, pois o maior peso de cacho e, conseqüentemente, de frutos aconteceu nos tratamentos em que foi procedido o ensacamento, que por sua vez apresentou uma tendência de menor teor de sólidos solúveis quando verdes. 


\subsection{CONCLUSÕES}

Nas condições do experimento, os resultados inferem o seguinte:

- O ensacamento de cachos propicia um menor intervalo de dias entre a emergência da inflorescência e o ponto de colheita de bananas destinadas ao mercado externo $\left(34 \mathrm{~mm}\right.$ de diâmetro nos frutos da $2^{\mathrm{a}}$ penca superior);

- O ensacamento de cachos não interfere sobre o intervalo de dias entre a emergência da inflorescência e o ponto de colheita de bananas destinadas ao mercado interno $\left(34 \mathrm{~mm}\right.$ de diâmetro nos frutos da $2^{a}$ penca inferior);

- Em nenhuma das épocas (10; 20 e 30 dias após a emergência da inflorescência) há aumento de peso de cacho em função do ensacamento;

- O ensacamento realizado 10 dias após a emergência da inflorescência, propicia aumento de comprimento e diâmetro dos frutos das pencas superiores;

- O teor de sólidos solúveis é menor em frutos ensacados 10 dias após a emergência da inflorescência;

- O ensacamento näo interfe sobre o peso de cacho; densidade; firmeza, relação polpa/casca e o pH de frutos verdes. 


\section{CONCLUSÕES GERAIS}

O estudo de proteção de cachos de banana com sacos de polietieno, nas cultivares estudadas, Nanicão e Grande Naine, comprovou que uma das principais vantagens é a redução do intervalo em dias entre a emergência da inflorescência e a colheita (E-C), em concordância com o relato de vários pesquisadores em trabalhos congenneres. Contudo, esse comportamento foi variável. De acordo com os resultados obtidos, aconteceram particularidades inerentes a cada uma das cultivares e objetivos da pesquisa, já que os experimentos foram diferentes em relação a esses aspectos. Na banana 'Nanicão', entre as épocas avaliadas, o E-C foi menor no inverno e verão, considerando-se o ponto de colheita para o mercado interno. Na banana 'Grande Naine' ocorreu menor E-C para o ponto de colheita para o mercado externo, independentemente, da época de realização do ensacamento após emergência da inflorescência, porém não houve diferença para o ponto de colheita para o mercado interno.

Frutos ensacados da cultivar Nanicão, apresentaram densidade menor que 1,00 no verão e outono. Esta caracteristica é importante devido a facilitar as operações de lavagem e tratamento químico no galpão de embalagem. Na cultivar Nanicão verificou-se também menor firmeza em frutos verdes submetidos ao ensacamento. Quanto ao teor de sólidos solúveis. observou-se diminuição em frutos de cachos ensacados de banana 'Nanicão' e em 'Grande Naine', sendo que na última ocorreu quando foi efetuado o ensacamento aos 10 dias após a emergência da inflorescência. Maior 
comprimento e diâmetro de frutos da $2^{\mathrm{a}}$ penca superior somente verificou-se em 'Grande Naine'. O ensacamento não interferiu sobre o peso de cacho, relação polpa/casca e pH em ambas cultivares estudadas.

É interessante ressaltar que, embora não tenha ocorrido diferença estatística, nos dois experimentos constatou-se que houve uma tendência do ensacamento favorecer o aumento de peso de cacho.

De acordo com os resultados obtidos e considerando-se o favorecimento de algumas caracteristicas nas cultivares estudadas, como a redução do intervalo em dias entre a emergência da inflorescência e a colheita, tendência de aumento de peso de cacho, densidade média de frutos inferior a 1,00 ('Nanicão'), afora outros possiveis benefícios não mensurados como aspecto visual dos frutos; conclui-se que o ensacamento como prática cultural foi positivo nas condições estudadas. Evidenciou-se que é necessário atentar para peculiaridades intrínsecas à cada cultivar, a época do ano e ao intervalo de tempo entre a emissão da inflorescência e a proteção do cacho. 


\section{REFERÊNCIAS BIBLIOGRÁFICAS}

ALVES, E.J. A bananicultura brasileira e o programa de pesquisa coordenado pela EMBRAPA em prol do seu melhoramento. Cruz das Almas: EMBRAPA, CNPMF, 1986. 50p.

ALVES, E.J.; OLIVEIRA, M.A. Manejo na colheita e pós-colheita. In: ALVES, E.J.; DANTAS, J.L.L.; SOARES FILHO, W.S et al. Banana para exportação: aspectos técnicos da produção. Brasilia: FRUPEX, 1995. p. 87-99.

ALVES, E.J.; OLIVEIRA, M.A. DANTAS, J.L.L. et al. Exigências climáticas In: ALVES, E.J. (Org.) A cultura da banana: aspectos técnicos, sócioeconômicos e agroindustriais. Brasília: EMBRAPA. SPI / Cruz das Almas: EMBRAPA, CNPMF, 1997. cap.2 p.35-41.

ALVES, E.J.; OLIVEIRA, M.A. Práticas culturais. In: ALVES, E.J. (Org.) A cultura da banana: aspectos técnicos, sócioeconômicos e agroindustriais. Brasília: EMBRAPA, SPI / Cruz das Almas: EMBRAPA, CNPMF, 1997. Cap. 12 p. $335-351$.

ANUÁRIO ESTATÍSTICO DO BRASIL - 1996, v.56, seção 3 - 52, 1996. 
BARNELL. H.R. Studies on tropical fruits: carbohydrate metabolism of the banana fruit during storage at $53^{\circ} \mathrm{F}$ and ripening at $68^{\circ} \mathrm{F}$. Annals of Botany, v. 5, n. 20, p. 608-645. 1941.

BERRIL, F.W. Bunch covers for bananas. Queensland Agricultural Journal, v.82, n.8, p. 53-62, 1956.

BLEINROT, E.W. Maturação da banana. Campinas: ITAL, 1972. 18p. (ITAL. Instruções Práticas, 3).

BLEINROT, E.W. Matéria prima. In: INSTITUTO DE TECNOLOGIA DE ALIMENTOS. Banana - cultura, matéria prima, processamento e aspectos econômicos. 2. ed. Campinas, 1985. p. 133-196.

CANN, H.J. Banana growing - plantation practices. Journal of Agricultural. Gazette, v.76, n.11, p. 672-678, 1965.

CARRARO, A. F; CUNHA, M. M. Manual de exportação de frutas. Brasilia: FRUPEX, 1994. 254p.

CARVALHO, H.A. de; CHITARRA, M.I.F.; CARVALHO, H.S. et al. Qualidade da banana 'Prata' previamente armazenanda em filme de polietileno, amadurecida em ambiente com umidade relativa elevada. Pesquisa Agropecuária Brasileira, v.24, n.5 p. 495-501, 1989

CARVALHO, V.D. de; PADUA, T. de; MORAES, A.R. de. Efeito da época de amostragem e do amadurecimento nas caracteristicas físicas, físicoquimicas e quimicas da banana 'Prata'. Revista Brasileira de Fruticultura, v. 4, p. $27-33,1982$. 
CHACÓN, S.I.; VIQQUEZ. F:; CHACÓN. G. Escala físico-química de maduración de banano. Fruits v.42, n.2 p. 95-102, 1987.

CHAMPION, J. El plátano: técnicas agrícolas y producciones tropicales. Barcelona: Ed. Blume, 1975. 247p.

CHITARRA M.I.F.; CHITARRA, A.B. Pós-colheita de frutos e hortaliças: fisiologia e manuseio. Lavras: ESAL/FAEPE. 1990. 320p.

CLAYPOOL, L.L.; DAVIS, L.D. The effect of could and modified atmosphere storage on the canning quality of cling peaches. Food Technology, v.13. n.3, p. 208-311, Mar. 1959.

DANIELLS, J.W.; LISLE, A.T.; O'FARRELL, P.J. Effect of bunch-covering methods on maturity bronzing, yeld, and fruit quality of bananas in North Queensland. Australian Journal Experimental Agriculture, v. 32, p. $122-125,1992$

DANIELLS, J.W.; O'FARREL, P.J. ; MULDER, J.C. et al. Effect of bunch coveringand bunch trimming on bananas in North Queensland. Queensland Journal of Agricultural A. Science, v. 44, p. 101-105, 1987.

DANTAS, J.L.L.; SHEPHERD, K.; SILVA, S.O et al. Classificação botânica. origem, evolução e distribuição geográfica. In: ALVES, E.J. (Org.) A cultura da banana: aspectos técnicos, sócioeconômicos e agroindustriais Brasília: EMBRAPA, SPI / Cruz das Almas: EMBRAPA. CNPMF, 1997. Cap. 1 p. $27-34$ 
DESAI, B.B.; DESHPAND, P.B. Chemical transformations in three varieties of banana (Musa paradisiaca Linneu) fruits stored at $20^{\circ} \mathrm{C}$. Mysore Journal of Agricultural Science v.9, p. 634.1975.

FAHN, A.; BENOUAICHE, P. Ultrastruture, development and secretion in the nectary of banana flowers. Annals of Botany, v. 44, n.1, p. 85-93, 1979.

FAO PRODUCTION YEARBOOK - 1996, v.50, p. 166-168, 1996.

GALÁN SAÚCO, V.G.; CABRERA CABRERA, J.C.; GOMES LEAL; P.M. The evaluation of different bunch covers for bananas (Musa acuminata) in the Canary Islands. Fruits, v.51, p. 13-24, 1996

GANRY, J. Influence du gainage des régimes de bananier avec une housse de polyéthylène, sur la température des fruits, dans les conditions de Neufchâteau (Guadeloupe). Fruits, v.30, n.12, p. 735-738, 1975.

GONÇALVES, J.S.; PEREZ, L.H.; SOUZA, S.A.M. Mercado internacional e produção de banana: a estrutura produtiva e comercial do complexo bananeiro mundial. Agricultura em São Paulo, v.41, p. 161-188, 1994.

HARMAN, J.; WATKINS, C. Use of the refractometer to estimate the soluble solids of fresh fruits. The Orchardist of New Zealand, v. 54, n.1, p. 35-37, 1981.

HEENAN, D.P. Bunch covers for bananas in the Northern District. Papua New Guinea Agricultural Journal, v. 24, p. 156-161, 1973. 
HOLDER, G.D.; GUMBS, F.A. Effects of water supply during floral initiation and differentiation on female flower production by Robusta bananas. Experimental Agriculture, v. 18, p. 183-193, 1982.

INSTITUTO ADOLFO LUTZ. Normas analíticas: métodos químicos e físicos para análises de alimentos. 3. ed. São Paulo, 1985. $533 p$.

ISRAELI, Y:; BLUMENFELD, A. Musa. In: HALEVY, A.H. (Ed.) Handbook of flowerig. Boca Raton: CRC Press. 1985. v.3, p. 390-409.

JOHNS, G.G.; SCOTT, K.J. Delayed harvesting of bananas with 'sealed' covers on bunches. 2 effect on fruit yeld and quality. Australian Journal Experimental Agriculture, v. 29, p. 727-733, 1989.

LASSOUDIĖRE, A. Quelques aspects de la croissance et du développement du bananier 'Poyo' em Cote d'Ivoire. IV. L'inflorescence. Fruits, v.33, p. $457-491,1978$.

LICHTEMBERG, L.A. Ensacamento do cacho de banana no campo. Informativo SBF, n.3, p. 8-11, set. 1996.

LOESECKE, H.W. von. Bananas: chemistry, physiology, tecnology. New York:: Interscience, 1950. 189p.

MARCHAL, J.; JANNOYER, M. Yield processes in banana: floral differentiation. Fruits, v. 48, n.1, p. 389, 1993. 
MARRIOT, J. Bananas - phisiological and biochemistry of storage and ripening for optimum quality. Critical Review of Food Science and Nutrition, v.13, n.1, p. 41-88, 1980.

MEDINA, J.C. Cultura. In: INSTITUTO DE TECLOGIA DE ALIMENTOS. Banana: cultura, matéria-prima, processamento e aspectos econômicos. Campinas, 1985. cap. 1, p. 1-131.

MOREIRA, R.S. Banana: teoria e prática de cultivo. Campinas: Cargil, 1987. 335p.

PALMER, J.K. The banana. In: HULME, A.C. The biochemistry of fruits and their products. London: Academic Press, 1971. v.2, cap. 2, p. 65105

PERUMAL, A.; ADAM, A.V. Bagging of giant cavendish banana stems in Honduras. I Effect on number of days from flower emergence to fruit harvest.. Tropical Agriculture, v. 45, p. 109-112, 1968.

RAM, M.; RAM, M.; STEWARD, F.C. Growth and development of the banana plant. III. A. The origin of the inflorescence and the development of the flower. III.B. The structure and development of the fruit. Annals of Botany, v. 26, p. 657-672, 1962.

REID, M.S. Product maturation and maturity indices. In: KADER, A.A. Postharvest technology of horticultural crops. Oakland: University of California, 1992. p. 8-11.

ROBINSON, J.C.; NEL, D.J. Banana bunchs covers in winter. Citrus and Subtropical Fruit Research, Information Bulletin, v.138, p. 5-6, 1984. 
ROBINSON, J.C. Sistems of cultivation and management. In: GOWEN, S. (Ed.) Bananas and plantains. London: Chapman \& Hall, 1995. cap. 7, p. $15-65$.

RYUGO, K. Fruit culture: its science and art. New York: John Wiley, 1988. cap.6, p. 107-168: Fruit growth and development.

SALOMÃO, L.C.C. Efeitos do envoltório plástico no desenvolvimento e na maturação pós-colheita de frutos de banana (Musa AAB) 'Mysore'. Viçosa, 1995. 104p. Tese (Doutorado) - Universidade Federal de Viçosa.

SAMPAIO, V.R.; SIMÃO, S. Banana: ensacamento de cachos logo após o florescimento. Revista de Agricultura, v.45, p. 75-77, 1970.

SCARPARE FILHO, J.A. Estudo do primeiro ciclo produtivo da bananeira 'Nanicão' (Musa sp. AAA) a partir de diferentes tipos de mudas. Piracicaba,1996. 72p. Tese (Doutorado) - Escola Superior de Agricultura "Luiz de Queiroz", Universidade de São Paulo.

SCOTT, K.J.; WILLS, R.B.H.; RIPPON, L.E.. The use of sealed polyethylene bunch covers during growth as a retardant to the ripening of bananas. Tropical Agriculture, v. 48, p. 163-165, 1971.

SGARBIERI, V.C; FIGUEIREDO, I.B. Transformações bioquímicas da banana durante o amadurecimento. Revista Brasileira de Tecnologia, v.2 p. 85-94, 1971. 
SHEPHERD, K. Morfologia e melhoramento genético da bananeira. In: SIMPÓSIO BRASILEIRO DE SOBRE BANANICULTURA, 1., Jaboticabal, 1984. Anais. p. $76-97$.

SIMÃO, S. Manual de fruticultra. São Paulo: Agronômica Ceres, 1971. $530 p$.

SIMMONDS, N.W. Los plátanos. Barcelona: Editorial Blume. 1973. 539p.

SIMMONDS, N.W.; SHEPHERD, $K$. The taxonomy and origins of the cultivated bananas. The Journal of the Linnean Society of London, v. 55 , p. 302-312, 1955.

SINGH U.R.; GANGWUAR, B.M.; SINGH, G.; et al. Growth and maturity studies on banana. Indian Journal of Horticulture, v.33, p. 19-25, 1987.

SOTO BALLESTERO, M. Descripción botânica. In: SOTO BALLESTERO, M. (Ed.) Banano: cultivo y comercialización San José: Litografia e Imprenta LIL, 1992. cap. $1, \mathrm{p}$.

SOTO BALLESTERO, M; SOTO, E.; SOLIS, P.; LÓPEZ, A. Siembra e operaciones de cultivo. In: SOTO BALLESTERO, M., ed. Banano: cultivo y comercialización San José: Litografia e Imprenta LIL, 1992. Cap.5, p. 211-365.

STOVER, R.H., SIMMONDS, N.W. Bananas. 3. ed. New York: Longman, 1987. $468 p$. 
THOMPSON, A.K.; BURDEN, O.J. Harversting and fruit care. In: GOWEN, S. ed. Bananas and plantain. London: Champman \& Hall, 1995. cap. 13, p. $403-433$.

TURNER, D.W. Banana plant growth. 1. Gross morphology. Australian Journal of Experimental Agriculture and Animal Husbandry, v. 12, $n$. 55, p. 209-215, Apr. 1972 a.

TURNER, D.W. Banana plant growth. 2. Dry matter production, leaf area and growth analysis. Aust. Journal of Experimental Agriculture and Animal Husbandry, v. 12 , n. 55 , p. 216-224, Apr. 1972b.

TURNER, D.W.; RIPPON, L.E. Effect of bunch covers on fruit growth and maturity in bananas. Tropical Agriculture, v. 50, p. 235-240, 1973.

WATADA, A.E.; HERNER, R.C.; KADER, A.A. et al. Terminology for the description of developmental stages of horticultural crops. HortScience, v. 19, n.1, p. 20-25, 1984. 